\title{
CANADIAN CITIZENSHIP IN EVOLUTION: \\ EXPLORING SIX CANADIAN CITIZENSHIP GUIDEBOOKS FROM 1946-2012
}

by

Sonya Anklesaria, Honours BA, University of Toronto, 2015

\author{
A Major Research Paper \\ presented to Ryerson University \\ in partial fulfilment of the requirements for the degree of \\ Master of Arts \\ in the program of \\ Immigration and Settlement Studies
}

Toronto, Ontario, Canada, 2017 


\section{AUTHOR'S DECLARATION FOR ELECTRONIC SUBMISSION OF A MAJOR RESEARCH PAPER}

I hereby declare that I am the sole author of this Major Research Paper. This is a true copy of the $\mathrm{MRP}$, including any required final revisions, as accepted by my examiners.

I authorize Ryerson University to lend this MRP to other institutions or individuals for the purpose of scholarly research.

I further authorize Ryerson University to reproduce this MRP by photocopying or by other means, in total or in part, at the request of other institutions or individuals for the purpose of scholarly research.

I understand that my MRP may be made electronically available to the public. 


\title{
CANADIAN CITIZENSHIP IN EVOLUTION: \\ EXPLORING SIX CANADIAN CITIZENSHIP GUIDEBOOKS FROM 1946-2012
}

\author{
Sonya Anklesaria \\ Master of Arts, 2017 \\ Immigration and Settlement Studies \\ Ryerson University
}

\begin{abstract}
Six educational guidebooks on the rights and responsibilities of Canadian citizenship for new immigrants have existed for approximately six decades, arriving alongside the first Citizenship Act in 1947. These guidebooks have been circulated by the Canadian government in the hopes of educating immigrants unfamiliar with Canadian culture and democracy as adopted from Great Britain. By understanding democratic theory and its relationship to citizenship education, this paper explores four themes (how various governments have viewed the terms and conditions of becoming a citizen, the "vision" of Canada presented in the various guides, the rights and responsibilities of citizenship, and what the guidebooks imply about social inclusion and the integration of new Canadians) within each successive guidebook in order to analyse how different governments over the years have prepared newcomers for citizenship in Canada, and what constitutes successful integration. By exploring the various themes of each guidebook, this paper finds that government-sponsored citizenship guidebooks are products of both domestic and international socio-political atmospheres, whose goal is to present to newcomers citizenship education, as well as a vision of Canada that reflects partisan attitudes toward various public policies.
\end{abstract}

Keywords: Citizenship, Immigration, Canada, Guidebooks, Education 


\section{ACKNOWLEDGEMENTS}

I would like to acknowledge the supervision of Dr Arthur Ross and thank him for his time, patience, commitment, discipline, constructive criticism and expertise on the subject matter.

I would like to acknowledge Dr. Myer Siemiatycki as my second reader and thank him for his guidance and approachable, friendly nature.

I am grateful for all the students of the 2015 Immigration and Settlement Studies cohort for their generosity of spirit, all the laughter, tears, and food shared, and for their constant support. And a special thanks to Julia Walters, Yana Zabalotnikava, Tear McDermott and Zain Shah for keeping me sane.

To Mark T., whom I have never met, but whose guidance and writing tips have made my academic journey a much more smoother process.

Lastly, my journey through this entire program would not have been anything without the support from my parents. I owe everything to you, I love you. 


\section{TABLE OF CONTENTS}

AUTHOR'S DECLARATION..............................................................ii

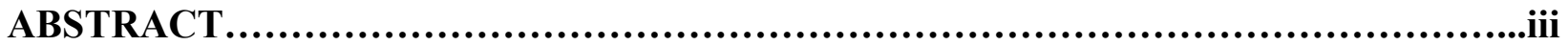

ACKNOWLEDGEMENTS...........................................................

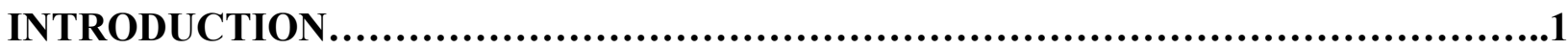

CHAPTER ONE

Theoretical Framework...........................................................................7

CHAPTER TWO

Citizenship Defined.............................................................................11

CHAPTER THREE

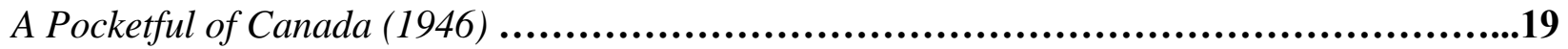

CHAPTER FOUR

How to Become a Canadian Citizen (1947).......................................................26

CHAPTER FIVE

Guide to Canadian Citizenship (1963)........................................................30

CHAPTER SIX

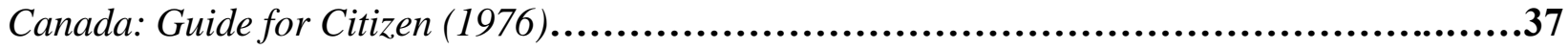

\section{CHAPTER SEVEN}

A Look at Canada (1995)......................................................................42

\section{CHAPTER EIGHT}

Discover Canada (2012)......................................................................48

\section{CHAPTER NINE}

Findings.....................................................................................58

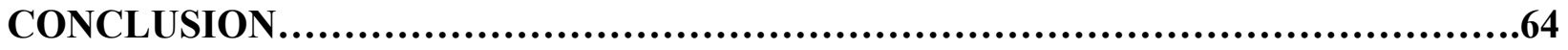

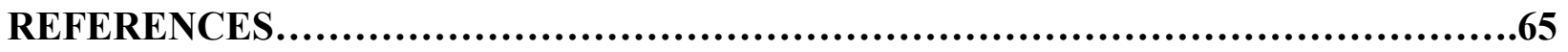




\section{INTRODUCTION}

Our "new Canadians" bring to this country much that is rich and good, and in Canada they find a new way of life and new hope for the future. They should all be made to feel that they, like the rest of us, are Canadians, citizens of a great country, guardians of proud traditions and trustees of all that is best in life for generations of Canadians yet to be. For the national unity of Canada and for the future and greatness of this country it is felt to be of utmost importance that all of us, new Canadians or old, have a consciousness of a common purpose and common interests as Canadians; that all of us are able to say with pride and say with meaning:

"I am a Canadian citizen."

Liberal Cabinet Minister Paul Martin Sr.

Distributed to approximately 250,000 immigrants per year (Citizenship and Immigration Canada, 2014), Canadian citizenship study guides have been designed to educate newcomers to Canada about Canadian history, values and government. They enable the government to present their specific vision of what it means to be a Canadian citizen. In 2009, the Conservative Minister of Citizenship, Immigration and Multiculturalism, Jason Kenney, released a new guidebook for citizenship testing entitled Discover Canada: The Rights and Responsibilities of Citizenship. The content of the new guidebook was both well received and heavily criticized. On the one hand, Discover Canada represented what critics called a neoconservative vision of Canada, because it focused a newcomers' attention on Canadian military achievements, the importance of the rule of law, and civic duties and responsibilities. While these subjects contribute to the newcomers' knowledge, when juxtaposed with the themes presented in the guidebook's predecessor, A Look at Canada (circulated by the previous Liberal government), critics of Discover Canada argued that it altered Canada's national image as a liberal, welcoming place, to a more rigid, right-wing country, emphasizing homogeneity, and de-emphasizing multicultural values (Chapnick, 2007; Joyce, 2014).

Although the new guidebook raised the eyebrows of politicians and scholars, changing what newcomers are expected to know as Canadian citizens is not a new phenomenon. Since the 
first Canadian Citizenship Act in 1947, which officially legalized the term "Canadian citizen," governments have been altering the parameters of how citizenship is defined, acquired, and viewed in Canada due to socio-political changes domestically and internationally. With the purpose of developing a distinctive Canadian citizenship identity, the guidebooks were initially created in order to aid newcomers of non-British descent to appear before courts, which determined their "worthiness" or eligibility for citizenship. Today, for those aged 14-64, a part of their eligibility is determined through a written test. In other words, as a result of changes in how successive Canadian governments present their understanding of citizenship to newcomers, "citizenship is in transformation" (Hebert and Wilkinson, 2002, p. 3). Regardless of these changes since 1947, official citizenship laws have been written with the purpose of defining the rights, responsibilities, and terms and conditions of Canadian citizenship for non-British and British subjects alike.

The purpose of this major research paper (MRP) is to present an historical and critical analysis of the evolution of how Canadian governments have perceived eligibility and the preparation for Canadian citizenship of newcomers. This will involve an examination of the six Canadian citizenship guidebooks in circulation between 1946 and 2012. These texts include: 1) John D. Robin's A Pocketful of Canada (1946) issued by the Canadian Council of Education for Citizenship; 2) the first official government document on citizenship, How to Become a Canadian Citizen (1947), published by the Department of the Secretary of State of the Liberal government of William Lyon Mackenzie King; 3) Guide to Canadian Citizenship (1963), published by the Liberal government of Lester B. Pearson; 4) Canada: Guide to Citizenship (1974); 5) A Look at Canada (1995), first published by Pierre Elliot Trudeau's Liberal government as an instructional pamphlet in 1977 during the debate surrounding the revision of 
the Citizenship Act, but updated as a guidebook under Jean Chretien's Liberal government; and lastly, 6) Discover Canada (2009), published under Stephen Harper's Conservative government. ${ }^{1}$

It is important to note that while this study focuses on six official government produced and funded documents, a series of supplementary, promotional publications were simultaneously released by the provinces and federal government during this period. ${ }^{2}$ These publications were designed to provide additional information and could be interpreted as simply providing general knowledge to newcomers, i.e., to prepare them for a citizenship application. They included subjects such as understanding the evolution of Canadian multiculturalism, recognising prejudice and discrimination, etc. While these documents are important, this study will solely focus on the six official guides in order to narrow the scope of a complex and broad subject.

The themes to be explored are neither unfamiliar, nor are they unchartered territory for scholars of citizenship; however, there is a dearth of literature on the evolution of how applicants were prepared for citizenship. To be sure, this study builds on existing citizenship literature by examining what citizenship means not through formal laws, policies or the constitution, but through a more reader-friendly, educational text. This study will add to existing citizenship literature by investigating how citizenship guidebooks of the past and present are tools utilised by the government to prepare and educate newcomer populations for life in Canada. In providing a comprehensive analysis of the evolution of Canadian citizenship, this study hopes to capture the rigour with which Canadian governments have prepared people, in the past, for appearing before a court to determine their eligibility for citizenship, and now, the written test of citizenship. How

\footnotetext{
${ }^{1}$ Each document utilized will be the latest, most updated version of the guidebook, which may not reflect the year of first publication presented above.

${ }^{2}$ See A Guide to Canadian Citizenship and Introduction to Canada (1967), "Citizenship in a Democracy" (1967), "Cultural Contributions of Newcomers to Canada" (1967), "Let's Take a Look at Prejudice and Discrimination" (1967), The Canadian Citizen (1977), A Newcomer's Introduction to Canada (1994), The Canadian Citizen (1995), You Asked About...Immigration and Citizenship (1999), Welcome to Canada: What You Should Know (2013), etc.
} 
has the government presented the information in the guides to better equip newcomers to become well-informed members of the Canadian community?

The discussion of citizenship will be explored as follows: First, it will consider the concept of citizenship and present a workable definition in the context of how it will be understood in this study; second, how the definition of citizenship has been influenced by Canada's colonial connection to Britain; and third, changing definitions of citizenship prior to and after 1947. These dimensions will frame the ultimate purpose of this study, that is, an explanation of the themes of these guidebooks which will be compared and contrasted to establish 1) how various governments have viewed the terms and conditions of becoming a citizen (what newcomers are expected to know as future Canadians); 2) the "vision" of Canada presented in the various guides, along with the emotions the guides were intended to evoke within the reader; 3) the rights and responsibilities of citizenship; and 4) what the guidebooks say or imply about, social inclusion and the integration of new Canadians.

This study recognises the importance of historical events that have influenced Canadian citizenship policy and have helped to shape our understanding of citizenship. However, due to constraints of time and space, this paper will not highlight who is not allowed into Canada: the heightened surveillance of migrants, and the exclusion and rejection of those that have been identified by the government as representing undesirable additions to the Canadian social and political fabric. These sentiments, and the historical contexts explaining them, find their expression more in terms of who was denied the possibility of entering Canada and becoming a Canadian citizen in the $19^{\text {th }}$ to the $21^{\text {st }}$ centuries based on prejudices such as race-based ideologies or threats to national security. This paper will not tackle the separate issue of citizenship denial throughout Canadian history, but rather focus on how, after the advent of mass post-war migration, the government clearly defined the requisites of citizenship for those of non- 
British descent, whose values, cultures and beliefs were considered to be in stark contrast with those of British-Canadians. Rather than making overarching conclusions about the future and meaning of citizenship, Canadian identity and culture, the goal of this MRP is to simply explain these booklets to understand what, over the years, governments have expected immigrants to learn about Canada.

Due to changes in immigration policy after $1962,{ }^{3}$ the cultural composition of Canada began to drastically change from a dominantly white, European population to one composed of nationalities from all over the world. As a result, the coalescing of diverse beliefs and values and the struggle to maintain one's culture while figuring out "how to be Canadian" has made the quest to perfect a distinctive citizenship identity in Canada only more complicated over time. Changes in citizenship policy to accommodate such needs have been made to ease the process of integration (i.e. multicultural policies, dual citizenship laws, the removal of preferential immigration for British subjects, citizenship by descent, etc.). However, the latest citizenship guidebook released in 2012 shocked many with its conservative, regressive views by presenting information with a harsher, stricter tone that was viewed as less welcoming than its predecessor. By emphasizing immigration to Canada as a privilege that is to be earned by foreigners, and not a fundamental right for humans to be able to move for a better life, Discover Canada reflected a widely quoted speech by Prime Minister William Lyon Mackenzie King in 1947, suggesting that It is not a 'fundamental human right' of any alien to enter Canada. It is a privilege... The people of Canada do not wish, as a result of mass immigration, to make a fundamental alteration in the character of our population..." (as cited in Kelley and Trebilcock, 2010, p. 317).

\footnotetext{
${ }^{3}$ New immigration regulations introduced in 1962 eliminated race and national origins as the main criteria to determine admissibly to Canada. The focus shifted to the applicant's skills and education.
} 
Understanding how each guidebook was built on the back of its predecessor, and why the latest guidebook reflects an historical, regressive step in forming a citizenship identity makes it important to explore the evolution of the six guidebooks. Although no one can predict the future, I argue that by examining the evolution of these guidebooks, their content, the socio-political context and setting in which they were formulated, and how the government prepares and screens newcomers for citizenship, one can understand both the transformations and patterns of citizenship culture in Canada and what aspects of Canadian citizenship the government believes contribute to a stable, distinctive, citizenship identity. 


\section{CHAPTER ONE}

\section{Theoretical Framework}

Democratic theory and its relationship to citizenship education will be presented as the theoretical foundations of citizenship education. This will be followed by a discourse on the evolution of Canadian citizenship. These theories will ground the content presented in the six guidebooks, and will act as a roadmap for readers of this MRP to assist them in understanding the progression of Canadian citizenship education for newcomers.

Schugurensky and Myers (2003) explain that “... the main purpose of citizenship education is the development of good democratic citizens" (p. 1). One must first understand what a "good democratic citizen" is in order to engage in a discussion of the education and information provided to newcomers in the six guidebooks. To present a fully realized, well-articulated democratic theory is an arduous task, for even the greatest scholars and is difficult to demonstrate in only a few pages. Political theorists have described the concept of democracy with a variety of diverse concepts. This has resulted in "a jumble of theory and practices that are often deeply inconsistent" (Dahl as cited in Hyland, 1995, p. 36), making the identification of a well-rounded democratic theory difficult.

For the purposes of this study, however, democratic theory will be explained generically, by focusing on basic principles that are by and large agreed upon. A statement made by United States President Abraham Lincoln in 1863 during the Gettysburg Address best articulates the overall essence of democracy: "government of the people, by the people, for the people" (Great American Documents, n.d.). According to Joseph Schumpeter (1976) democracy is an “... institutional arrangement for arriving at political decisions in which individuals acquire the power to decide by means of a competitive struggle for the peoples vote" (p. 269). Although expressed differently, and with different intended audiences, Lincoln and Schumpeter both explain 
democratic theory as the power given to the people to elect their government leaders, who in turn make decisions on behalf of the population for the good of citizens - what is better known today as representative democracy. A "democratic citizen" is therefore one who actively participates in decision-making processes, and upholds the values of that nation.

Jean-Jacques Rousseau's concept of the social contract adds another perspective to the state-citizen relationship:

...the association will defend the person and goods of each member with the collective force of all, and under which each individual, while uniting himself with the association and others, obeys no one but himself, and remains as free as before" (Rousseau as cited in Dahl, Shapiro and Cheibub, 2003, p. 2).

In Rousseau's estimation, the individual forgoes certain freedoms after electing a state representative; however, in return receives protection from the state against threats to his (or her) social welfare. The citizen is essentially a free (wo)man, but is obligated to actively abide by laws and values of the state, just as the state is obligated to ensure the citizen's well-being.

Schugurensky and Myers (2003) explain the importance of citizenship education in a contemporary democratic state. ${ }^{4}$ Citizenship education, according to the authors, has two main orientations: the first is conservative, and the second is progressive. The conservative orientation privileges the reproduction of the existing societal status quo, or seeks to re-implement a socioeconomic order that previously existed. The context of this education is primarily concerned with "national narratives, historical and geographical facts, and the functioning of government institutions" (Schugurensky and Myers, 2003, p. 2). In this sense, good citizens adopt a passive

\footnotetext{
${ }^{4}$ For the purposes of this MRP, theories of citizenship education will not be applied to academic learning institutions, but rather to the citizenship guidebooks for newcomers.
} 
attitude towards citizenship: their addition to the social fabric in no way undermines the societal status quo.

The alternative, as explained by Schugurensky and Myers (2003), is a progressive orientation toward citizenship education, which emphasizes societal transformation and social justice, and works to reduce inequalities. A progressive orientation towards citizenship education calls for the critical examination of the existing status quo, specifically in regards to "gender, race and class structures... [ultimately] preparing citizens for inclusive political processes of deliberation and decision-making" (Schugurensky and Myers, 2003, p. 3). The goal of this type of education is to encourage a newcomer to question the status quo, engage in learning and discourse, and not only ask how to improve Canada from a socio-economic standpoint, but also to seek solutions and participate to the extent possible in all levels of politics. This form of education encourages an active attitude toward citizenship, igniting in the newcomer a passion and thirst for knowledge. The newcomer feels welcome, believing that his or her addition to the Canadian social fabric will improve, rather than upset the status quo. Ultimately, what makes the progressive orientation toward citizenship unique is its emphasis on inclusivity.

In a democratic state, both of these orientations toward citizenship education have merits and complications; however, it is important to remember that though their approaches differ greatly, the ultimate goal of both orientations, is the cultivation of good, democratic citizens. On one hand, a conservative orientation towards citizenship not only maintains the status quo, but also strengthens it over time. It allows for a Canadian citizenship culture that is easily identifiable and well characterized. It strengthens nationalism, democracy, and capitalism in Canada, honouring our history and unifying people as one homogenous group.

The "room for improvement" idea challenges this concept. Though progressive citizenship education does not drastically change the meaning of citizenship, it creates space for a 
dialogue on how to improve citizenship culture and identity in Canada. Under this orientation, characteristics of citizenship are often fluid, dynamic, and unstable, and can potentially confuse newcomers and longstanding citizens on what exactly Canadian citizenship embodies if we allow it to be subject to constant scrutiny and evolution. This does not exactly provide a newcomer with the stability they need during an already uncertain time; however, because this approach to citizenship focuses on inclusivity, this model of education fosters a more positive attitude, and does not encourage a "fear of the other" attitude. This "fear of the other" attitude is a consequence of a conservative orientation toward citizenship, which may solidify characteristics of Canadian culture that perceives Canadians as members of one homogenous group. This model of citizenship inadvertently maintains a vertical stratification of racial hierarchies in society, with utmost privilege given to Anglo-Saxons, and their culture and values. In response, the progressive orientation approaches citizenship education through the lens of not just equality but equity as well. The goal for advocates of social equality is to continue to keep Canada inclusive by accommodating newcomers from different cultural and socio-economic backgrounds.

If the main purpose of citizenship education is to develop good, democratic citizens of Canada, why is it so difficult for politicians, scholars, and philosophers to reach consensus on what a good education should entail? In the case of Canada, it is extremely complicated. As a country moulded by British colonialism, which at one time was populated almost entirely by Europeans, the social composition of Canada has over many decades been transformed through mass immigration. Those in charge of informing citizenship education continue to face ethical, pedagogical, and political choices: on the one hand, there is a concern amongst those who fear the rapidly changing ethnic composition of Canada. Those who hold this view press for the conservative orientation of education in the hopes that, while ethnic composition may change, British-orientated values do not. 


\section{CHAPTER TWO}

\section{Citizenship Defined}

Although Canada became independent in 1867, it was imbued with an explicitly British notion of citizenship and values system (Bauder, 2014). Gradually, a dialogue developed on how to adjust citizenship to suit not only the First Nations people, the French, and Anglo-Saxons who were present prior to Confederation, but also for those who arrived after Confederation, including foreigners and "aliens." As a result, Canadians have become concerned with four dimensions of citizenship: "1) the conceptual foundations of citizenship and identity; 2) policies and institutional goals; 3) citizenship set within the realities of Canadian society; and 4) citizenship education" (Hebert and Wilkinson, 2002 p. 4).

Today, citizenship is generally understood as the process of acquiring legal status in a country that grants rights and protection to its residents. In Canada, this status can be acquired through birth, naturalization, or family ancestry (“Citizenship," 2015). Citizenship becomes the proverbial glue that holds people together, binding them as "children" of a common "parent" state, transforming a country into a nation, ultimately determining who belongs to that nation (Bloemraad, 2006). Citizens are regulated by, and are obligated to follow laws that outline the responsibilities of citizenship — when these laws are broken and citizenship is betrayed, it is considered one of the most heinous crimes (Bloemraad, 2006; Fraser and Gordon, 1996; Kaplan, 1993). From this perspective, citizenship can be understood as a legal construct.

Citizenship, however, is not one-dimensional, and is more complicated than a simple legal definition. There are multiple layers to understanding citizenship, and one's comprehension can change depending on the context in which it is used (Fraser and Gordon, 1996). Historian Charles Taylor believes that to employ "a single model of citizenship is not a possibility in this

\footnotetext{
${ }^{5}$ An individual coming to work and live in Canada who was not a British subject.
} 
country" (Taylor as cited in Kaplan, 1993, p. 105). This is a plausible argument; in Canada, citizenship has been greatly transformed from being closed and exclusive, to being open and inclusive. Once defined by geographical borders and a common history, citizenship has moved from having a unitary and stable meaning, to one that is multidimensional and ever shifting (Hebert and Wilkinson, 2002). Furthermore, as a concept that is operationalized through inclusion and exclusion, citizenship invokes varying degrees of emotion through a sense of belonging, thus making it complicated for the individual's, and the nation's collective identity (Hebert and Wilkinson, 2002). In this sense, "citizenship is both a legal and emotional concept" (Kaplan, 1993, p. 50).

In 1946, H.M. Tory, Chairman of the Canadian Council of Education for Citizenship, explained that "Because Canada is so vast and so complex, few Canadians have an adequate appreciation of their own country" (as cited in John Robin's Pocketful of Canada, 1946, p. v). What does this mean for how Canadian citizenship is perceived? As a nation that was officially independent from Britain in 1867, Canada is regarded as a fairly new country and as such, the settlement of such a vast land was the results of the efforts of millions of immigrants over a span of hundreds of years. Though this chapter does not present a history of immigration and settlement in Canada, an overarching, historical understanding of immigration both before and after Confederation becomes the backdrop for understanding why citizenship policies changed, and why there was a difference between the naturalization process for British subjects and foreigners. It is, therefore, logical to first look at Canada's colonial connection to Britain, and how citizenship changed (or did not change) when Canada became independent in 1867.

\section{Canada's Colonial Connection to Great Britain}

The history of Canadian immigration is not straightforward, though this discussion will be as linear as possible. Prior to the arrival of British and French settlers in the $16^{\text {th }}$ and $17^{\text {th }}$ 
centuries, Canada was a land inhabited by various Aboriginal groups (First Nations and Inuit people), living harmoniously according to their own laws and unique ways of life. The aggressive, complicated, and ruthless takeover of Aboriginal land by French and British settlers led to colonisation and mass immigration. Under British imperialism, Aboriginals and the British maintained a relatively amicable state-to-state relationship, which boded well for both the British and Aboriginals. However, because after Confederation Canada did not have it's own formal citizenship act, Aboriginal people were regarded by the Canadian government as wards of the state and were treated as second-class citizens: they were not allowed to vote or own land in Canada but were, however, allowed to serve with the Canadian military and did so in both the First and Second World Wars.

The Seven Years War (1756-63) ended France's position as a colonial superpower in Canada. France formally ceded power to the British; however, the presence of a large, established French-speaking population created the bicultural and bilingual foundations of Canada. Although settlers had been arriving in Canada centuries prior to Confederation, Knowles (2007) explains that it was not until the end of the Napoleonic Wars in 1815 that Canada (and other colonial countries) saw the greatest number of immigrants from Great Britain arrive-well over a million individuals by the end of the $19^{\text {th }}$ century. Preceding this, Canada had received immigrants from the United States (both Americans and Loyalists), France, Ireland, and Scotland.

After 1763, Canada became a colon of Great Britain’s protégée, a colony embodying British values, laws, and culture. As a result, the demand for immigrants from Great Britain was high, and free land and provisions were offered to many in order to promote emigration, and keep Canada as British as possible (Knowles, 2007). Colonisation entailed that "newcomers are not treated as outsiders or foreigners, but as new members of society" (Bauder, 2014 p. 12). In this 
sense, nation-building in settler societies like Canada can best be understood as a whiteimperialist settler project (Kaplan, 1993). Simply put, those arriving from Britain were preapproved, and qualified for citizenship because they were British citizens, spoke English, and held allegiance to the monarch: ideally, they were expected to maintain the culture and values of Great Britain in Canada. In this regard, early Canadian citizenship, which was inherited from Great Britain, is best described as colonial citizenship.

\section{Changing Definitions of Citizenship: Prior to and After 1947}

Although Canada was granted independence from Britain in 1867, Canada was still viewed as a nation that was simply an extension of Britain, and citizenship policies, including how to acquire it and who was eligible for it, did not change. Prior to the 1900s, the naturalization process of those coming to Canada was focused on those coming from Britain. During this period, citizenship in Canada was a concept meant for British subjects, and was solely understood as legal status. A well-constructed naturalization track for foreigners and aliens was not clearly spelled out in the $19^{\text {th }}$ century because there was simply no demand for it. However, with the growth of industrialization and consumerism, the number of non-British immigrants began to grow, especially in the late $19^{\text {th }}$ century. As a result, Canada was faced with the challenge of granting citizenship to a growing incoming population that was not British, raising the issue of how these people would become assimilated, democratic citizens.

The Immigration Act of 1910 defined citizenship as "a person born in Canada; a British subject with domicile; and a person naturalized under the laws of Canada" (Kelley and Trebilcock, 2010, p.161). The Naturalization Act 1914 (adopted from the British Naturalization Act 1870 and the British Nationality and Status of Aliens Act 1914) made clear that a "Canadian citizen"- even after Confederation—was still regarded as a British subject. Therefore, for British subjects at the time, citizenship continued to mean loyalty to the Crown. To obtain citizenship 
through naturalization, British subjects had to be domiciled in Canada for two years, and eventually were sworn in before a judge.

Aliens who planned to permanently remain in Canada had to file an application for citizenship. Under the Naturalization Act, applicants were to appear before a judge and prove that: 1) they had lived in one of the Crown's dominions for at least five years; 2) they were of good moral character and have an adequate knowledge of English or French; 3) they intend to reside in said dominion; and, 4) they will agree to take the oath of allegiance (Government of Canada; Kelley and Trebilcock, 2010). Section 2.7 of the Act outlined grounds for the revocation of citizenship of aliens. They included a person who 1) has engaged in war against the side of the Crown; 2) has within five years of naturalization been sentenced to imprisonment for a period longer than twelve years; 3) was not of good character at the date of the grant of the certificate; 4) has lived outside of any one of the dominions for longer than seven years.

Furthermore, legal provisions under the Naturalization Act were sexist in nature: only the male head of the family could only apply for citizenship, and his wife and children were dependants of the husband. Married women arriving at the same time as their husbands were not eligible to apply for naturalization until the husband was granted his certificate, and until then were classified under the "disability" category. Additionally, a fifth provision under section 2.7 of the Act, called for the revocation of citizenship for the alien wife and children of a man whose citizenship was revoked, should the husband fail to fulfil the requirements of citizenship. In this sense, citizenship for resident aliens was not equal for men and women. Furthermore, even if a resident alien met all the requirements for naturalization, judicial review of an application could still deny citizenship to aliens, increasing their vulnerability, and thereby maintaining control on the intake of undesirable immigrants, especially during periods of instability and war (Kelley and Trebilcock, 2010). 
Despite minor changes to citizenship law, things stayed relatively stable between 1919 to 1946. While the doors to Canada were virtually closed during the Great Depression, immigration reopened in the late 1940s as Canada experienced an economic boom. Drastic changes to immigration patterns affected political discourse regarding not only the application process for naturalization and citizenship, but also the manner in which immigrants should be integrated into mainstream society. The Liberals under Prime Minister Mackenzie King were not ready to entirely abolish Canada's racialized immigration policy. However, the King government recognized that changes in citizenship laws were needed in order to ensure the successful integration of aliens, while maintaining the overall cultural integrity of Canada (Knowles, 2007). With immigration numbers increasing rapidly, uniformity of practice regarding who belongs, and how to integrate them, became a question of urgency that required immediate action. What steps were to be taken in order to successfully build a national, uniform community in Canada? A solution was articulated on May $1^{\text {st }}, 1947$ in the form of the first Canadian Citizenship Act, which led to the release of the first guidebook for citizenship education in Canada.

Following the traumatic events of the Second World War, citizenship policy after 1947, though still racially-based, was relatively more inclusive. Applicants from the "old" commonwealth and the United States would continue to receive preferential treatment as the government's first choice of immigrants to Canada; however, Asian residents of Canada would finally be allowed to apply for naturalization, and the Chinese Immigration Act of 1923 was repealed in 1948. Furthermore, as a result of membership in the United Nations, Canada also ... recognized a moral obligation to assist in meeting the problem [of refugees]... [and sent] immigration officers to examine the situation among refugee groups...towards the early admission of some thousands of their 
number (House of Commons debates, 1962, as cited in Knowles, 2007, p. 164)

In addition, the Act stipulated that married women would no longer be regarded as persons with a “disability”, women, as well, as men, could gain citizenship in Canada (Government of Canada, 1947, p. 3). Though race continued to structure the hierarchy of admissible immigrants (with those from Asia seen as the least desirable), emerging concepts of the "welfare state" and “multiculturalism” began to take root (Kelley and Trebilcock, 2010; Knowles, 2007).

The year1947 was an important one in Canadian citizenship policy because it was the first time the definition of citizenship was broadened to reflect the changing times and changing immigration patterns in Canada. Citizenship not only moved from a male to a gender-neutral definition, but was also beginning to recognize (although barely) that racial diversity could not be ignored. The government could no longer assume (based on immigration over the last 50 years) that a majority of those arriving in Canada would be from Great Britain and understood Canada's view of democracy, culture, and ways of life. There was a growing awareness that Canada had changed, and that its ethnic composition would continue to change. As a result, the Canadian government would no longer be able to assume that aliens would absorb what it meant to be a Canadian simply by assimilation, or by any education they received prior to their arrival. In other words, the government realized that some form of education was necessary for those not arriving from Britain or Commonwealth countries. Furthermore, while on tour of a Canadian war cemetery, Liberal Cabinet Minister Paul Martin Sr. realized that many of the graves of those who fought for Canada in both World Wars were of various ethic backgrounds. While the purpose for mass immigration at this time was primarily economic, Paul Martin Sr. realized that those fighting for Canada should not regarded as "British subjects", but rather as Canadians who fought 
for their home, allowing a greater push for a distinct Canadian citizenship identity (Government of Canada, 1945). 


\section{CHAPTER THREE}

Following the first Citizenship Act in 1947 and human rights recognition following the atrocities of the Second World War, Canada very slowly began to open it's doors to refugees seeking a better life or fleeing religious or political persecution (though the government was adamant on maintaining Canada's European ethnic composition). In subsequent years, however, notable changes to immigration policies were made in 1952, 1962, 1967 and 1977 (Kelley and Trebilcock, 2010). The most significant of these changes included the abolition of preferential treatment of commonwealth immigrants, the decrease and eventual abolition of discriminatory policies, and the creation of policies focusing on economic growth (i.e., the Point Based Assessment System for skilled immigrants), which increased the entry of much-needed highly skilled workers and educated immigrants. Citizenship in Canada shifted greatly in meaning, with the focus changing from the maintenance of Canada's Anglo-British character to the economic growth and the equality of immigrants from various national backgrounds.

While the question of who is allowed entry was, and always will be defined by formal immigration laws, citizenship in Canada can further be compartmentalized to embody "personal, social, temporal and special" dimensions (Sobel, 2015, p. 12). What this means is that the guidebooks are tools that not only aid newcomers to prepare for the citizenship test but also provide guidance on how to socialize and assimilate in Canada to maximize integration into Canadian society and fulfil their responsibilities as Canadian citizens. As a result, a series of six official citizenship guidebooks were distributed throughout the years in the hope of educating incoming immigrants about the importance of Canadian history, government, and values.

This chapter examines each successive guidebook by exploring their content and patterns through the themes presented in the introduction. The goal is to understand both historic and contemporary government narratives about what it means to be a Canadian citizen and what is 
expected from a citizen. Has the government has taken a progressive or conservative approach to citizenship education, and how do these narratives affect the integration and inclusion of newcomers to Canada?

\section{A Pocketful of Canada (1946)}

According to Chapnick (2011), the first guide to Canadian citizenship predates the first Citizenship Act. A Pocketful of Canada was written and published in 1946 by John D. Robins, a professor of English at Victoria College. Although this guidebook was not written by a government official, it was sponsored and circulated by the Canadian Council of Education for Citizenship, whose president, H.M. Tory, approached citizenship education (measured by today's standards) from an unconventional perspective. He believed that for newcomers to fully understand and embrace the spirit of Canada, they had to appreciate not only the nation's history, but the lives of those who had experienced hardships and triumphs when settling Canada (Chapnick, 2011; Tory as cited in Robins, 1946). Robins and Tory believed that this form of education would be best delivered through an anthology of short stories, poetry, photography, speeches, and statistical data. Constructed from a variety of sources, the goal of this guide was to present "Canadian-ism" in a style that would resonate emotionally with readers. This guidebook is thus presented as a narrative of the "everyday Canadian."

Unlike subsequent guidebooks, this 400-page text was not mandatory for newcomers to Canada to read. It has, however, come to be known as the first comprehensive guidebook that was "characteristically Canadian, in mood or content, or both" (Chapnick, 2011, p. 23). Although A Pocketful of Canada is not considered to be the first official guide to citizenship education by some scholars (Sobel, 2015) because it predates the first citizenship law in 1947, it is a very important piece of literature in citizenship education, simply because it was intended for 
citizenship education and served as a prototype for future citizenship guidebooks (Chapnick, 2011).

The first theme I explore is what A Pocketful of Canada conveys about how the government viewed the terms and conditions of becoming a citizen, that is, what newcomers were expected to know as future Canadians. In the guide's table of contents, the titles of each section are cryptic and vague: they include "From Sea to Sea"; "Snake Fence Country"; "SignPosts Cultural"; "Documents and Statistics", etc. The text of A Pocketful of Canada emphasizes history and stories of everyday life. It makes sense that a guidebook would (in part) focus on everyday life in Canada, even if quotidian activities vary from geographical region-to-region, and household to household. What day-to-day life in Canada is like is recounted through stories such as "the settler's wife alone at night" (p. 37), describing the life of a young woman as her husband hunts for food for days at a time; "sugar-making" (p. 41), about a family tapping sap from a tree to enjoy a cold Canadian treat; "the merchant's tale"(p. 91), a poem about the hardships faced by an Ontarian merchant in a cold winter and his quest to settle with his family; "my financial career” (p. 208), a story retelling a man's first experience depositing money at a bank, etc. Many stories regarding day-to-day life revolve around a man's struggle to settle and build a life in Canada. There are very few stories featuring a woman as the main character or that provide a woman's perspective on life in Canada. ${ }^{6}$

The guidebook depicts the history of Canada through stories and poetry, providing readers with the essence and spirit of events through emotional, first-hand accounts. For example, stories focus on the symbolism behind the selection of Ottawa as Canada's capital city (p. 9), the Halifax explosion in 1917 (p. 25), and the fur trade (p. 81); there are stories and poetry about Canada's various regions (p.16), and about soldiers' and their wives' experiences during the First

\footnotetext{
${ }^{6}$ See "the settler's wife alone at night" (p. 37); "sugar-making (p. 41); "this was my brother" (p. 199)
} 
World War (“The Patchwork Quilt" p.171). This material constitutes a qualitative, subjective, and biased method of presenting history, and it would therefore be very difficult for the reader to communicate the content within this guide in an informative manner without compromising the integrity and tone of the text. The only quantitative, factual information in A Pocketful of Canada consists of dates and geographical locations, as well as information from a primary source titled The Founding of Québec, written by Samuel de Champlain, the founder of New France and Québec City (p. 211). The final chapter of the guidebook, titled "Documents and Statistics," is the only factual chapter in A Pocketful of Canada; it presents excerpts from legislation (e.g., The British North America Act, p. 391; The Statute of Westminster, p. 397); a map of Canada (p. 410); and the lyrics to $O$ Canada in English and French along with the musical score (p.412). Lastly, a section entitled "Description of Canada" explains the geography of Canada in each province and the role of the Governor-General in Canada, federal ministries, and provides various tables listing past prime ministers and governor generals, the racial origins of the population from 1871 to 1941, and the population of Canada from 1871 to 1941 by province.

The second theme this study analyzes is the "vision" of Canada presented in the guide, along with the various emotions the guide attempted to evoke in the reader. The compiler's vision of Canada as revealed in the very first chapter of A Pocketful of Canada, is entitled "Canada the Unknown." As this guide is an anthology, I examine this chapter first to understand why the compiler chose this narrative to represent Canada over all others. What was the first impression of Canada the compiler wished to portray to newcomers? The first sentence in "Canada the Unknown" is "No one knows my country, neither the stranger, nor its own sons" (Hutchison as cited in Robins, 1946, p. 3). This is a powerful statement: as a vast country founded on the values of the British, the French, and Indigenous peoples, how does one define Canadian culture and values? Who are truly the Canadian people? The paragraph goes on to explain, "My country has 
not found itself nor felt its power nor learned its true place. It is all visions and doubts and hopes and dreams" (Hutchison as cited in Robins, 1946, p. 3). The rest of the chapter is a metaphorical narrative depicting Canada as a young thoroughbred horse that is problematic because it is not yet trained nor fully grown; however, that does not mean it lacks beauty or potential. The chapter concludes: "We are young, my brothers, and full of doubt, and we have listened too long to timid men. But now our time is come and we are ready" (Hutchison as cited in Robins, 1946, p. 5).

Robins and Hutchison present Canada as a young country, and by geopolitical standards, Canada at this time was in its infancy. The author and compiler make it very clear that because Canada is still young, it has not yet completely developed as a nation-state, and only time will allow Canada to come into its own. This chapter implies that this country is no longer an extension of Britain, and because the "child" has grown up and left the "parent," the child has to figure out how to fend for itself. Even though the child has yet to make a name for itself, it is unique and possesses beautiful characteristics that only those who have spent time with this child would understand. Therefore, to strangers or foreigners, Canada without Britain is an enigma, but to the citizen, Canada is simply home, a home whose beauty and value can be appreciated only by those who experience it. Newcomers reading A Pocketful of Canada could relate to this chapter because metaphorically speaking, Canada was at this time an "immigrant country" on the global map. Like an immigrant person, Canada is doubtful, hopeful, excited, and passionate to grow up to become an influential and powerful nation. Through creative writing, poetry and songs, these sentiments are conveyed throughout the subsequent chapters depicting historical events and everyday life.

While the existence of the Indigenous population in Canada is not ignored in this guide, these communities are not portrayed in the best light. In some passages, they are referred to as "savages," embodying the "manners and customs of a savage life" and Aboriginals are compared 
to the white man, who is described as civilized (Mackenzie in Robins, 1946, p. 81). No direct reference is made to the fact that there was an Indigenous population prior to the arrival of Europeans. In some stories, they are insignificant background characters. Lastly, while this guide is not directly affiliated with any particular religion or denomination, there is mention of "God" in many passages, ${ }^{7}$ and many stories reference Christian holidays such as Christmas (see p. 162, "On Christmas Day in Canada"). Canada is therefore presented as a Christian country.

A Pocketful of Canada does not explicitly lay out the rights and responsibilities of citizenship, most likely because a formal law on Canadian citizenship did not exist at the time, though expectations of the rights and responsibilities did. Furthermore, the compiler's intention when putting together this guide was, as mentioned, to present the essence and spirit of belonging and settlement in Canada through poetry and stories — not the rights and responsibilities of citizenship. However, the content of the guide often seems to allude to two main ideas regarding a newcomer's responsibility to Canada, which is the duty to be loyal, and the idea that hard work will pay off if a newcomer endures the hardships of settlement in a new country.

This rhetoric ties into the third theme: what does the guidebook say, or imply, about social inclusion and the integration of new Canadians? A Pocketful of Canada does not explicitly refer to the integration and inclusion of racial minorities. The guide gives the impression that the only racial minorities in Canada were the Indigenous people and the African-Americans who arrived from the United States but, as mentioned previously, they are generally minor characters who simply provide background in the stories they appear in. In actuality, a number of racial minorities lived in Canada at this time, including the Chinese and Sikh populations who had arrived in the late 1800s. Even White Canadians were racially divided by their European heritage. A discourse on integration may be absent from A Pocketful of Canada because the guide was

\footnotetext{
${ }^{7}$ See pp. 98, 101, 121, 130, 189, and 227.
} 
written at a time when there was no demand for integration and inclusion policies. The majority of the content in the guide was written before the 1930s, when Canada's immigration policies were still racist in nature, and the majority of the population were Anglo-Saxons from Great Britain.

However, the absence of any mention of the integration of racial minorities actually speaks volumes. Assimilation of those admissible to Canada at this time (preferably Europeans), not multiculturalism, is expressed through these stories by solely stressing Canadian-adopted Anglo-Saxon values and ways of life. A Pocketful of Canada was an incremental step in creating "an overarching national identity and convincing [newcomers] to adhere to it" (Chapnick, 2011, p.22). For these reasons, A Pocketful of Canada approaches citizenship education with a conservative orientation. 


\section{CHAPTER FOUR}

\section{How to Become a Canadian Citizen (1947)}

One year following the publication of A Pocketful of Canada, the volume How to Become a Canadian Citizen was published. Written by and circulated under the Liberal government of William Lyon Mackenzie King, this guidebook is different from the earlier guidebook in a few ways. First, it is a humble 62-page pocketbook divided into three chapters. Second, unlike $A$ Pocketful of Canada, this text is written in prose, providing straightforward facts and history, without the added flourish of poetry, story and song. Lastly, because this guidebook is a companion to the passage of Canada's first Citizenship Act, the content of this guidebook does not express the spirit and essence of Canada in the same way intended by A Pocketful of Canada, but is a more straightforward text on how to effectively prepare for an appearance before a citizenship judge who will determine whether or not the applicant is of "good character" and thus eligible to become a Canadian citizen. This guide reflects the Act itself, which establishes criteria for obtaining citizenship and the circumstances under which it can be lost or revoked. As such, "the good character citizen" is the narrative that permeates How to Become a Canadian Citizen (Sobel, 2015).

How did the government view the terms and conditions of becoming a Canadian citizen in How to Become a Canadian Citizen? What are newcomers expected to know before appearing before a judge? The three chapters in this guidebook are titled: "The Canadian Citizenship Act"; "Facts About Canada"; and "Questions and Answers." Chapter one takes up just over half of the guidebook and comprises the Citizenship Act in its entirety. It informs readers of all they need to know regarding their application for citizenship, what documents and knowledge are needed before appearing in front of a judge, information regarding citizenship for British and alien 
applicants and for women and children, the various ways in which a person could lose their citizenship and, lastly, general information about fees and forms.

Chapter two of the guide presents information about Canada, i.e. its history, geography, natural resources, and constitution and government, along with a description of all the provinces in Canada. Chapter three of the guide presents a series of 116 questions and answers regarding the three levels of government in Canada and the history of Canada (e.g., Question: who was the first European to visit Canada? Answer: John Cabot in 1497). This chapter specifically states at the outset that these questions are informative only, and may or may not be asked of the candidate by the presiding judge. Sobel's (2015) breakdown of the thematic components of the guidebook provides a quantitative analysis of the importance of certain themes over others: $46 \%$ of the guide's content is on citizenship procedures, $18 \%$ on Canadian history and geography, $7 \%$ on the government system, and $4 \%$ on the economy (p. 19).

What vision of Canada is presented in How to Become a Canadian Citizen, and what emotions did it intend to evoke in the reader? Unlike A Pocketful of Canada, this guide does not utilize artistic forms of writing to play on the emotions of a newcomer and incite feelings of patriotism, hope, appreciation, etc. It is, as its title suggests, an instructional guidebook on how to be a Canadian citizen of good character. Although this guide does not dismiss the efforts and hardships of settlers, Canada is presented through a more objective lens as a country officially independent from Britain, not through Confederation but rather through its first legislation on citizenship. Whereas A Pocketful of Canada portrays Canada as a "youth upon the eve of its manhood" (Hutchison as cited in Robins, 1946, p. 3), How to Become a Canadian Citizen is an expression of Canada's coming-of-age. This is exemplified in the requirement that immigrants renounce their foreign nationality for Canadian citizenship: British subjects and other aliens are no longer British or "foreign" once Canadian citizenship is acquired, and likewise, a Canadian 
woman who marries an alien renounces her Canadian citizenship upon marriage, regardless of her birthright or naturalized status (p. 25).

The cost of applying for citizenship at this time was approximately $\$ 8.50$, which (after inflation) in 2016 is equal to approximately $\$ 103$ (Bank of Canada, n.d.). This was the standard fee for one person, and it did not include an applicant's spouse or children, and fees were higher for aliens. In fact, a citizenship application could cost as much as $\$ 25$, which is approximately $\$ 300$ in 2016 . These fees were very high for newcomers to Canada, especially for alien immigrants who were paid less than French- and English-speaking workers at this time (Knowles, 2007). Citizenship was therefore a luxury that was difficult to access and afford.

How to Become a Canadian Citizen explicitly states the legal responsibilities of citizenship by exploring the Citizenship Act in chapter one. In terms of civil participation in society, this guide is vague and does not ask the new citizen to be involved in any specific activity. However, rhetoric in this guide demonstrates that it is the responsibility of alien candidates to know English or French and understand the responsibilities and privileges of Canadian citizenship (p. 13). Nowhere in this guide are the "responsibilities and privileges" of citizenship explicitly stated; however, provisions of the Citizenship Act, explaining qualities that demonstrate "good character," including the absence of a criminal record, and fulfil civic responsibilities (which this paper assumes to be activities such as voting).

Similar to A Pocketful of Canada, How to Become a Canadian Citizen makes no explicit reference to inclusivity or the integration of racial minorities. There is even less mention of the Indigenous population in Canada in this guidebook that in the earlier one. The guide states that Indigenous peoples “descend from peoples who migrated from Asia dim ages ago" (p. 33). In chapters two and three, there is no mention of any other racial minority in Canada, which suggests Canada as a nation solely inhabited by British and French settlers. Chapter two does 
state that, "Canada is the result of immigration from other lands," although no reference is made to any lands in particular (p. 33). Only in chapter one of this guide can the reader infer that people other than those descended from English and French settlers inhabit Canada because there are clauses regarding citizenship for aliens.

How to Become a Canadian Citizen is the first guidebook that refers to "good character" as a requirement for Canadian citizenship. Since individual citizenship judges determined good character, no uniformity of practice can be established. The guide states, "the definition of 'good character' raises a point involving wide differences of opinion as some judges are more strict than others" (p. 14). Referring to the 1947 Citizenship Act, judges defined good character as loyalty to Canada, acceptance of Canadian customs, values and beliefs stemming from Canada's Commonwealth history, obedience to Canadian laws, and adequate knowledge of either English or French. Judges also expected applicants to embrace social and cultural customs "mostly linked to Western Europe, and more precisely the United Kingdom" (Sobel, 2015, p. 19). These are the conditions that the prospective citizen needed to fulfil to obtain "full and complete membership in the Canadian family," (p.1) a metaphor that conveys the belonging and inclusion alluded to in the forward of this guidebook. Although a Liberal government at the time published this guide, there is no reason to believe that this book would not have resonated with those whose primary loyalty in 2016 would be to the Conservative Party (Chapnick, 2011). Like its predecessor, How to Become a Canadian Citizen has conservative orientations to citizenship education. 


\section{CHAPTER FIVE}

\section{Guide to Canadian Citizenship (1963)}

The Guide to Canadian Citizenship was published in 1963 by the Department of Citizenship and Immigration when Lester B. Pearson was Prime Minister. It is a 94-page booklet that portrays a person with citizenship as a full member of Canadian society. Compared to How to Become a Canadian Citizen, this guidebook contains more descriptions of expected behaviours of citizens than actual mechanics of how to apply for citizenship. It also provides greater certainty to the candidate in terms of what to expect during the judge's examination by focusing on the responsibilities and privileges of citizenship. For this reason, Guide to Canadian Citizenship represents the narrative of the "responsible citizen" (Sobel, 2015).

This guidebook does not follow the same thematic structure as How to Become a Canadian Citizen. However, it establishes themes that continue to appear in subsequent guidebooks. These themes are expressed through the titles of the Table of Contents and include: "The Story of Canada"; "People and Life in Canada"; "The Land"; "Resources and Industries"; "How Canada is Governed"; and "Rights and Responsibilities of a Citizen." Due its descriptions of the land and everyday life in Canada, this guidebook shares more similarities with A Pocketful of Canada than with How to Become a Canadian Citizen, although it differs greatly from Pocketful in the style in which the information presented.

In Guide to Canadian Citizenship, there are no definitive statements explaining what a newcomer "must" know (e.g., "the newcomer must have knowledge of English and French"). Information is presented sequentially, accompanied by a few photographs; there is no way for the reader to understand which chapters, sections, facts or paragraphs are more important than others

and, as a result, feels compelled to learn all the details provided by the guidebook. By presenting 
the information in this style, the guide suggests that an in-depth knowledge of Canadian history is a prerequisite for citizenship.

Upon closer examination, however, the characteristics of a good citizen can be found in the last chapter, "Rights and Responsibilities" (p. 82), which explains that the responsibilities of a citizen are "mainly voluntary and not enforceable by law" (p. 83). As stated in the guidebook, "Good citizenship in a democracy... is based on a sense of responsibility" that includes partaking in activities such as voting and community affairs (p. 84). However, even though voting is described as a voluntary activity, the greatest amount of space in this guidebook is dedicated to explaining the political and electoral process in Canada (p. 63-82) followed by descriptions of Canada's history in "The Story of Canada" (p. 1-18). Thus, the guidebook implies that newcomers are expected to have a firm understanding of Canadian history and the electoral process, and that this understanding will prepare them for voting and life in a democratic society. The last chapter of this guidebook, "Appendices" (p. 87), contains the oath of allegiance and the lyrics to $O$ Canada and God Save the Queen, and discusses what to expect when appearing at citizenship court.

Guide to Canadian Citizenship presents a vision of Canada as the epitome of a modern democracy. At various points, the guide emphasizes (without expressing any sense of pride) the fact that Canada is a representative democracy (see p. 33, 63, 64, 78, and 82 to 85). The guide makes it clear that believing in democracy (as understood in Western societies) and defending the democratic way of life is an important prerequisite of citizenship. Along with describing what "rule of the majority" means and outlining its importance in a democracy, the guide states that being a member of a democracy is an honour, as Canada's "belief is that the best political system is one in which as many people as possible have a share in making decisions and taking responsibility" (p. 63). This is further exemplified by the frequency of words such as "member" 
(46 mentions) and "group" (39 mentions) throughout the guidebook (Sobel, 2015). Communal rights may at times trump individual rights, however, the individual is never ignored as “...the value of the individual [is] basic to democracy" (p. 63).

In terms of history, this guidebook presents Canada as an unoccupied treasure discovered by Scandinavians in about the year 1000. The history then goes on to mention various explorers who arrived in Canada, the establishment of New France, etc. Canada is presented as a lucky find for explorers and settlers who cultivated an empty, vast land. It is not until page three that Indigenous peoples are first mentioned. The guide states: "Soon after their arrival in Canada, the French began trading with the Indians" (p. 3). There is not a single mention of the prior occupation of land in Canada by Aboriginal people in the long chapter discussing Canadian history. They further explain on page 5 that "violent wars broke out among the Indian tribes who had allied themselves with either the French or British settlers...communities were attacked by hostile Indians and the inhabitants killed.” In this description, Aboriginals are seen as a violent group of people who are responsible for their own demise. Canada and those who arrived to settle it are presented as heroic while Aboriginals are presented as savages. However, it is not until page 19, well into the next chapter of the book, "People and Life in Canada," that the guide mentions that Indians were living here thousands of years before the first Europeans arrived.

The "Rights and Responsibilities of Citizenship" chapter in Guide to Canadian Citizenship comprises only two pages. On the subject of rights, six rights and freedoms of individuals extrapolated from the Canadian Bill of Rights (1960) are listed. These include freedom of religion and speech, and the right of the individual to equality before the law and to the protection of the law, existing for everyone "without discrimination by reason of race, national origin, colour, religion or sex" (p. 82). Further rights are listed with in depth descriptions, such as the right to a fair trial and freedom of movement. These are followed by a 
paragraph on "consideration for the rights of others," which explains that in a democracy, no freedom is absolute and each one has reasonable limitations.

As mentioned, the responsibilities of citizenship are portrayed as voluntary. Although this is the reality of citizenship, no other guidebook before or after Guide to Canadian Citizenship explicitly describes citizenship responsibilities as voluntary. Taking the initiative to vote, engage in community affairs and work is what makes for full, democratic citizenship in Canada. The guidebook eloquently states that King Louis XIV of France once remarked, "I am the state," but in Canada, a citizen can say, "We, the people, are the state" and, therefore, the main means of engaging in society is through civic and social volunteer activities (p. 84-85). This statement makes the reader feel like they can be part of something important and that their voice matters, invoking a sense of duty through an emphasis on responsibility

Social inclusion and integration are more prominent in this guidebook than in its two predecessors. The chapter "People and Life in Canada" notes that Canada has progressed as a country over many years. Women, both married and unmarried, occupy various careers; work in agriculture is decreasing due to the rapid expansion of an industrial economy; and there is no rigid class structure in Canada because people constantly move from one place to another when better employment opportunities are offered. This makes the newcomer feel that whether they settle in Halifax or Vancouver, their experiences coast to coast will be relatively the same.

This chapter goes on to explain that almost all Canadians are immigrants or descendants of immigrants. They are encouraged to maintain their traditional cultures, which have contributed to the cultural diversity that is characteristic of Canada. Significantly, Aboriginals in this guidebook are described in a two-sentence paragraph. It describes a "very small part of the 
Canadian population"8 of Indians and Eskimos who lived here for thousands of years before the arrival of Europeans. The rest of the chapter discusses the British and French as the two main cultures in Canada, and by extension, English and French as the two official languages.

While A Pocketful of Canada provides a table listing the various ethnicities by population in Canada, Guide to Canadian Citizenship is the first guidebook that discusses the various ethnic groups in Canada (e.g., Germans, Ukrainians, Scandinavians, Arabs, Chinese, etc.), including where they tend to settle and the types of jobs they occupy. The guide also discusses the main religions practiced in Canada (Protestant, Catholic, Jewish, etc.). This section explains that all people in Canada enjoy religious freedom, and one of the ways to get involved within one's community is through a religious organization. The guide also presents information on where various ethnic groups have established small communities in Canada. This provides a feeling of reassurance for the newcomer who may be hoping to find a place in Canada where they can feel at home. Although the guide stops short of encouraging the development of ethnic enclaves and certainly does not discourage assimilation, the guide attempted to ease newcomers' anxiety and transition when reading about the acceptance of various ethnic and religious groups in Canada.

Lastly, this chapter provides ways in which newcomers can get involved in activities that contribute to Canadian identity and the expansion of Canadian culture. There is a heavy emphasis on the arts, including theatre, ballet, music, literature, radio, film, etc., and newcomers are encouraged to participate in art forms. The point is made that development of art in Canada expands Canada's culture domestically and on an international scale. The guidebook encourages Canadians to listen to the Canadian Broadcasting Corporation (CBC) in English or French, which will provide newcomers with "news reports, commentaries and talks...telling them about life in

\footnotetext{
${ }^{8}$ According to Statistics Canada, 261,000 registered Aboriginals lived among 18 million Canadians in 1961; resulting in approximately $1 \%$ of the total population (Statistics Canada).
} 
Canada" (p. 26). The chapter then goes on to explain the importance of compulsory education for children, regardless of gender, and encourages post-secondary studies. Adult education is also emphasized for newcomers in the form of university classes, public lectures, film showings, etc., which are presented as an opportunity to learn the languages of Canada and about Canadian history and development. Lastly, this chapter provides information on the importance of various volunteer organizations (p. 32), taking advantage of labour unions (p. 33), and enjoying sports and the outdoors (p. 34).

An emphasis on democracy and responsibility is woven throughout this guidebook: it plays a role in all chapters and themes. There is a sense that the reader is being persuaded to accept that no better form of government exists than democracy, because only through democracy is every individual's opinion valued. Perhaps this emphasis on democracy and its responsibilities can be attributed to the fact that this guidebook was drafted during the Cold War (1947 to 1991). Highlighting Western democracy during an international battle against communism seems like a logical strategy to communicate to new citizens the types of political and social organizations they should be supporting in order to be recognized as full Canadians.

Overall, Guide to Canadian Citizenship provides newcomers with a substantial amount of information to prepare for life in Canada. This guide explains better than its predecessor what constitutes "good character"- that is, a law-abiding person who actively participates in the community — and goes so far as to suggest many avenues for the candidate to engage in these kinds of activities in order to prove to a judge that they are worthy of citizenship. Guide to Canadian Citizenship sets a precedent for presenting citizenship education in a comprehensive, historically chronological style, emphasizing themes such as the electoral process, regionalism, and the rights and responsibilities of citizenship, which appear in subsequent guidebooks. Even though the tone of this guide seems designed to strengthen nationalism during the Cold War, 
there were many additions to this guidebook, especially those discussed above regarding "the vision of Canada" and integration and social inclusion, that demonstrate that Guide to Canadian Citizenship was written with a progressive orientation toward citizenship education. This includes subsections on various ethnic groups and religions, promotion of the idea of multiculturalism, encouragement of newcomers to join a mosaic and not a melting pot, and encouragement of newcomers to actively participate in the democratic process. 


\section{CHAPTER SIX}

\section{Canada: Guide for Citizenship (1976)}

The fourth guidebook, Canada: Guide for Citizenship, was first published in 1974 under Prime Minister Pierre Elliot Trudeau's Liberal government. ${ }^{9}$ This guide is 68 pages in length; however, this is the first citizenship guide in which the entire content is presented in both official languages, thus the content of this guidebook is only 34 pages in length. This guidebook is significantly shorter than the previous one, which was triple its length. Throughout its entirety, the focus of the guidebook is the reader, emphasizing not just how the newcomer can become part of Canada, but how Canada can become part of the newcomer. More than any other previous guidebook, this guide places equal emphasis on maintaining one's culture and becoming part of Canadian culture. As a result, Canada: Guide for Citizenship represents a narrative of the "wholesome citizen" (Sobel, 2015), that is, a citizenship who does not surrender any part of his/her identity in the process of becoming a Canadian and acquiring citizenship.

According to the guide's table of contents, newcomers should have knowledge of "Geography," "People and their Work," "History," "Cultural Growth and Education," "Government," and "International Relations." The greatest amount of space is dedicated to "Geography" (six pages) and "Government" (four pages). In the introduction, new Canadians are taught the importance of having knowledge of English or French: "newcomers find it an advantage to learn at least one of these languages for their everyday use in Canada" (p. 3). This is followed by a statement, which explains that knowledge of one or both official languages does not mean that a person must give up their own heritage. It further explains the importance of multiculturalism in Canada and the emphasis the government places on multiculturalism, placing Canada on a unique pedestal as we "develop an identity drawn from all parts of the world" (p. 3).

\footnotetext{
${ }^{9}$ This MRP will be utilizing the most up-to-date version of this guidebook, published in 1976.
} 
However, throughout the guidebook, knowledge of the two official languages is placed on a higher level than knowledge of other languages; this is exemplified not just in the introduction, but in the guide's explanation of the importance of bilingualism in the chapter "Cultural Growth and Education" (p. 18) and the fact that this is the first guidebook to be presented in both languages in one publication. Overall, like all other guidebooks before it, Canada: Guide for Citizenship, expects new Canadians to have a general grasp of Canadian history and the political system, although not as in depth as compared to Guide to Canadian Citizenship.

The last chapter, titled "Citizenship" (p. 28), has a question and answer format, providing straightforward answers to questions about Canadian citizenship. These include: "When was the Citizenship Act passed?"; "What are the principle qualities of a good citizen?"; "How does a citizen participate more directly in Canadian decision making?", etc. This chapter informs the reader about what the government expects newcomers to know regarding the acquisition, possession, and maintenance of citizenship without publishing the Citizenship Act itself.

It is difficult to discern what vision of Canada is presented throughout this guidebook due to the relatively small amount of content. It is very much like past guides in that it emphasizes volunteering and participation as values of Western democracy, which serves the question as to why it was necessary to draft and circulate a new guidebook in the first place. Whereas the last guidebook, Canada: Guide for Citizenship, utilizes the word "volunteer," this guidebook emphasizes the importance of a citizen being an "active" member of society. Active membership includes constantly learning about Canada's past, engaging in debates about Canada's future, joining organizations, and engaging in adult learning classes, etc. Therefore, while newcomers are encouraged to enrich the local culture with their own heritage, they are also encouraged to participate in their community in any way they can. 
Lastly, as mentioned (compared to the previous three guidebooks), there is a new emphasis placed on bilingualism. Perhaps this is linked to Canada's historical context at the time, which was characterized by intense political debates surrounding the sovereignty movement in Québec, which began in the late 1960s. Even though this guidebook closely matched its predecessor perhaps it was produced and circulated because producing a guidebook in both English and French may have been a logical strategy for the Liberal government to demonstrate the inclusion of Québécois culture and language. This guidebook was produced during a time when Québec felt threatened by Anglophone assimilation, which they feared would result in the eventual demise of French culture in Canada. As a result, while all the previous guidebooks mentioned the two official languages in Canada, Canada: Guide for Citizenship is the first guidebook that presents a "vision" of Canada as a bilingual nation, placing equal emphasis on both English and French culture and language. One section in the chapter titled "Cultural Growth and Education" (p. 18) even discusses at length what is being done to promote bilingualism in Canada.

Unlike the previous guidebook, there is no single chapter dedicated to the rights and responsibilities of the new Canadian. However, six specific behaviours of a citizen are provided in the last chapter, "Citizenship," in answer to the question, "What are the principle qualities of a good citizen?" These qualities include community involvement, investing in the common good, obeying the law, respecting the rights of others, keeping up with the affairs of Canada, and using one's talents and experience to solve social problems. Following this chapter is a list of addresses and phone numbers of the offices of elected officials, providing the means for citizens to contact community leaders in order to seek changes in policy.

The chapter titled "Citizenship" also enumerates the rights of Canadian citizens, including the right to vote, the right to hold a Canadian passport, and the right to stand for office. This is a 
stark contrast with the list of rights outlined in Guide to Canadian Citizenship, which lifted its much longer list of rights straight from the Canadian Bill of Rights. The additional rights mentioned in Guide to Canadian Citizenship are not mentioned anywhere in this new guidebook. Although the Canadian Bill of Rights law bestows both types of rights, perhaps the authors thought that it would be of greater use for newcomers to be aware of the importance of exercising political conventions that are less obvious. It is noteworthy to mention that while all the other guidebooks emphasize the importance of having knowledge about politics and actively voting, Canada: Guide for Citizenship is the only guidebook thus far to have added the right to participate in elected office and goes so far as to encourage the reader to exercise this right. This is the only guidebook that creates a positive association between the active citizenship of newcomers and the future wellbeing of Canada as a country.

To determine what Canada: Guide for Citizenship says about social inclusion and integration, I first looked at the introduction page, where along with learning English and French, citizens are encouraged to maintain their heritage and contribute to a multicultural Canada. No previous guidebook stressed the importance of maintaining one's traditions and culture right in the introduction. Furthermore, the first sentence of the chapter titled "History" describes the forefathers of Canada as the Inuit and Indians who arrived 20,000 years ago. Granted, utilizing the term "Indian" to describe Aboriginals is derogatory; however, no other guidebook, before or after this one, described Aboriginals as the "forefathers" of Canada. Despite the atrocities and cultural genocide these groups have endured over a span of hundreds of years since the arrival of Europeans, to finally have their status as the forefathers of Canada recognized instead of being considered just people who inhabited Canadian land is a small step toward the reconciliation and inclusion of Aboriginals. 
This guidebook recognizes important events in history that have promoted multiculturalism in Canada such as the Official Languages Act (1969) and the passing of Canada's multiculturalism policy in 1971. The chapter on "Cultural Growth and Education" provides an in-depth explanation of the importance of bilingualism in Canada and the reasoning behind Canada adopting a multicultural policy. The government's belief was that Canada's unique cultural identity is ironically made up of hundreds of cultural identities that work together to achieve the well-being of Canadians. To foster multiculturalism is Canada's duty, as immigrants come to Canada to improve not just their own lives but Canada's social and economic standing as well. In fact, Canada: Guide for Citizenship is the only guidebook of the six published that includes many photos of members of ethnic minorities in Canada (see pages 12, 17, 20, 21, and 28). Lastly, like the previous guidebook, Canada: Guide for Citizenship places emphasis on Canadian art forms and the ways in which art has influenced Canadian culture. However, unlike the last guidebook, Canada: Guide for Citizenship does not encourage the newcomer to engage in these activities, but rather highlights how expressions of art can bring different types of people closer together. After all, art has no language.

Canada: Guide for Citizenship embodies a concise approach to citizenship education with a progressive orientation. For the first time, a guidebook was produced that highlighted (just enough) important events and information regarding Canadian history and the political system, for a newcomer to know. It is the first guidebook that is inclusive and encouraging of the various cultures of Canada, and the first to bolster bilingualism. This guidebook does not outline citizenship responsibilities or education in detail. However, the chosen set of citizen characteristics in this guidebook is more aspirational — and demanding of active participationthan its predecessors. 


\section{CHAPTER SEVEN}

\section{A Look at Canada (1995) $)^{10}$}

As well as being an incarnation of its predecessors, A Look at Canada, a 47-page guidebook published in 1995 under Jean Chrétien's Liberal government, was the first citizenship guidebook to prepare applicants for a new citizenship-granting process. Shortly before the production of this guidebook, the Government of Canada realized (at a time of economic austerity and higher levels of immigration) that an interview process with a judge was becoming increasingly demanding of resources (Joyce, 2014; Sobel, 2015). It would therefore be more feasible to place a group of candidates for citizenship in one room, where they would take a written test with questions similar to those asked at a hearing with a judge. The government decided that in lieu of the outdated interview process, candidates for citizenship would write a standardized test that would require a candidate to answer a minimum of 12 answers out of 20 correctly in order to become a Canadian citizen. Those who failed this written test would be examined orally. In this sense, A Look at Canada was prepared with the narrative of "the testready citizen" in mind (Sobel, 2015).

What the government expects newcomers to know as citizens is spelled out in the first page of the guide. Under "Message to Our Readers" the guide stated that: "To become a Canadian citizen, you must be able to speak English or French. You must also learn about voting procedures and Canada's history and geography, and know the rights and responsibilities of Canadian citizenship" (p. 3). The section goes on to explain what is meant by "rights" (singling out equality rights, language rights, and religious freedom as the most important of many) and

\footnotetext{
${ }^{10}$ This guidebook was originally a short pamphlet published in 1977 as a supplementary guide. It became an official guidebook in 1995. It underwent many editorial changes since its release in 1995, most likely due to changes in Prime Ministers and governments. Although none of the changes significantly altered the fundamental character of this guidebook, this paper is utilising the latest edited 2005 edition.
} 
what responsibilities citizenship entails (respect for Canadian laws and for the rights and freedoms of others, and willingness to participate in local communities to help make Canada a better place). A closer examination of the table of contents demonstrates that this guidebook is not unlike its predecessors. Chapters include sections on the various regions of Canada (the Atlantic, Central, West Coast, etc.), the levels of government in Canada, voting procedures and the federal election, a map of Canada, and the history of Canada. What makes A Look at Canada different from its predecessors, however, are added chapters that educate readers on themes that were not explored as deeply (or at all) in previous guidebooks. These themes include Aboriginal peoples of Canada, the Canadian justice system, and citizenship rights and responsibilities; in addition, numerous photographs and illustrations highlight these themes throughout the guidebook. The guide is therefore more informative in terms of citizenship than predecessor guidebooks, because of its emphasis on language, history, geography, and laws.

According to Joyce (2014), Canada is presented to readers in this guidebook as a "peaceable kingdom," and rhetoric and phrases throughout A Look at Canada support her observation. For example, A Look at Canada takes pride in the diverse cultural composition of Canada, emphasizing that the Canadian Multicultural Act recognizes this diversity, promotes equality (as entrenched in the Charter of Rights and Freedoms), and allows Canadians to live and work harmoniously (p. 8). Additionally, this guide gives the impression that the government works closely with Aboriginal peoples of Canada to protect their rights, heritage and culture by briefly mentioning historical treaties and their recognition in the 1982 Constitution Act (p. 14 and $15)$.

Furthermore, this guide explains that Canadians believe in working together and helping one another, and stresses the importance of communal ties and getting to know one's neighbours and community (p. 8). What further contributes to the vision of Canada as a peaceable kingdom 
is the guide's emphasis on sustainable development: not only do Canadians care about one another, but we care about protecting our environment; the chapter on sustainable development lists ways for Canadians to be environmentally conscious. Lastly, the physical appearance of the guidebook reflects its purpose, to help readers pass the citizenship test. It has colourful pictures that complement the text, colourful fonts, simplified language, bolding of key words and terminology that are important for studying and review, and empty pages for note-taking. This guide demonstrates that the government wants to encourage newcomer to learn, and pass the test.

The guidebook contains very little information about Canada's military history or colonial tendencies of the past. Multiculturalism and tolerance are themes that are stressed throughout the guidebook, a history that (apparently) is rooted in the nation's foundations. Richler (2012) explains that Canada has been acknowledged as an "open and welcoming country, one in which a mythology of rescue, human generosity and the possibility of starting anew flourished because the idyllic story has mostly been true" (p. 34). This perspective and that of Joyce's (2014) "peaceable kingdom" comprise slightly skewed and biased versions of Canadian history (especially when compared to the earlier guidebooks), but nonetheless, they are representative of a generally accepted narrative that Canada is a peaceable nation.

Throughout this guidebook, the responsibilities of a citizen are mentioned numerous times. ${ }^{11}$ These references are most clearly and explicitly stated in a section titled "Citizenship Rights and Responsibilities" (p. 38). In two pages, this section emphasizes the Canadian Charter of Rights and Freedoms and lists some of the many rights Canadians enjoy. A small information box on page 39 reiterates the responsibilities briefly mentioned throughout the book: to vote in elections, help others in the community, care for and protect the environment, obey Canada's laws, and know English or French. Chapnick (2011) explains that while the constant emphasis on

\footnotetext{
${ }^{11}$ See page 5, 10, 11, and 33 of $A$ Look at Canada.
} 
the Charter in A Look at Canada may be reflective of a liberal agenda, certain responsibilities listed are reflective of conservative values (e.g., knowledge of English or French to participate in the community, p.1). However, I argue that these responsibilities are presented more as an itemized list of options than as a guideline for mandatory action. This is likely because the reader is studying for an exam that will require correct answers to multiple-choice questions. As such, the rights and responsibilities listed are generic enough to be reflective of either a liberal or conservative values.

This guidebook speaks to social inclusion and integration more than any of its predecessors. This may be attributed to the Canadian Charter of Rights and Freedoms and the Multiculturalism Act, which did not exist when the early guidebooks were written. This guide is highlights protections for minorities and their rights provided by the Charter. Secondly, the emphasis on cultural and racial equality throughout the guide gives the impression that Canada is the best place to be for any new immigrant. This may be due to the higher levels of immigration that the Government of Canada was experiencing at the time.

As mentioned, unlike other guidebooks, A Look at Canada dedicates an entire chapter to Aboriginal peoples and continues to mention their presence and contributions throughout. The chapter on Aboriginal peoples explains who they are and their connection to Canada, and provides descriptions of the three main groups (First Nations, Métis, and Inuit) of contemporary Aboriginal people in Canada. There are photographs of totem poles and Aboriginals in their native attire, smiling at the camera. However, there is no mention whatsoever of Aboriginal history after the arrival of white settlers to Canada nor any mention of the havoc wreaked on Aboriginal communities as a result of colonialism. One sentence alludes slightly to their current, poor socio-economic condition: "Canada is working with them to improve their economic 
situation and general quality of life" (p. 15). However, it is unlikely that a newcomer would gain much awareness of the hardships Aboriginals in Canada face today from this one sentence.

Despite its emphasis on equality and multiculturalism, most of the photographs of people in A Look at Canada are photographs of white people with the exception of a few photos of Aboriginals and one photo of a black woman. Although the guide emphasizes freedom of religion and respect for cultural differences (p. 7), there are no depictions — in words or images — of any celebration of cultural or racial diversity. Furthermore, page 1 of the guide states, "Canadians are proud of the peaceful and tolerant society they have built." Use of the word "tolerant" in this context implies an attitude that respects racial diversity and multiculturalism for the purposes of economic prosperity. However, it does not signify a high level of social acceptance, as the word "tolerant" implies that one has to put up with something, but not perhaps embrace it wholeheartedly. Lastly, one of the responsibilities of Canadian citizens is to "eliminate discrimination and injustice"; however, no real guidance or direction is provided on how to go about accomplishing this.

A Look at Canada is unlike the guides that were published before it, because it was written with a progressive orientation in mind. This guidebook is the first to have an explicit goal of preparing candidates for a written citizenship test. While this guidebook is more readerfriendly than its predecessors due to the attractive features of its layout and presentation, it also lacks substance in terms of the quality and depth of its content. This guidebook may cover more topics regarding Canada than any of the other guidebooks; however, they are very basic in explanation and lack important details regarding some of the themes addressed throughout the chapters. No mention is made of Canadian history prior to Confederation, nor is there any reference to contemporary controversies (e.g., on the topic of Québec, the section notes, "The province preserves and promotes the historic language and culture of its French-speaking 
citizens" but nothing is said about the separatist movement in that province (p. 21). Canada's military achievements are not mentioned, nor is the role that Canada has played internationally as a combatant in both World Wars and as a peacekeeper in areas of conflict throughout the world. Neither is Canada's commitment to refugees mentioned. A Look at Canada paints the portrait of a kind, gentle nation (for the most part), free of historical or contemporary controversy (Chapnick, 2011).

While no information in the guide is incorrect, the tone, language and presentation of the guide presents an inaccurate and skewed vision of Canada as a country where all relationships are amicable. It is reflective of the Citizenship Act of 1977 and a series of small amendments to it in the following years, which ensured that citizenship laws were more inclusive of adopted children and those born outside of Canada to either a Canadian mother or father, regardless of their marital status. Therefore, it also suggests a more inclusive definition of citizenship. The realities of everyday living that were presented in A Pocketful of Canada are absent from this guidebook. As a result, $A$ Look at Canada seems to be more about helping people pass their citizenship test in the most efficient way possible by providing them with very clear information about Canada in a use-friendly style, instead of presenting them with everyday realities that both the native population and newcomers face. 


\section{CHAPTER EIGHT}

\section{Discover Canada: The Rights and Responsibilities of Citizenship (2012)}

Discover Canada: The Rights and Responsibilities of Citizenship (henceforth to be referred to as Discover Canada) is the sixth and current guidebook for citizenship education in Canada. It embodies the narrative of the "loyal citizen" (Sobel, 2015). This guidebook closely resembles Guide to Canadian Citizenship (1963), but approaches citizenship education with the most conservative orientation to date. Formulated by Stephen Harper's Conservative government in 2012, Discover Canada is a 66-page document that was designed to expand and upgrade the quality of testable content presented to newcomers. According to the Conservative government, Discover Canada is a more accurate representation of authentic Canadian values, beliefs, and history. It is considerably denser in content in order to provide a thorough account of the responsibilities of Canadian citizenship to the newcomer. Discover Canada places more emphasis on Canada's colonial connection to Great Britain and on the importance of the Canadian armed forces than on Canadian aspirations such as environmental leadership and sustainability (Chapnick, 2011).

Although Discover Canada does not stray far from the themes and content presented in $A$ Look at Canada, there is a stark difference in tone and attitude between each guidebook. The first page of this guidebook presents the oath of citizenship in both English and French, followed by a short explanation of the importance of the oath. The guidebook explains that the oath symbolizes Canada as a constitutional monarchy in which full loyalty is owed to the Sovereign: "Canada is personified by the Sovereign just as the Sovereign is personified by Canada" (p. 2). While this oath is mostly symbolic, the government's emphasis on it exemplifies the notion that in some way, Canada continues to be part of Britain's colonial enterprise, and therefore a newcomer's 
loyalty is not just to Canada, but to a monarch in a different country as well (whose roles and titles are now also symbolic in that country).

Secondly, the guide makes it very clear to newcomers that citizenship is a responsibility that is not to be taken lightly: this is the first guidebook that includes "rights and responsibilities" in its subtitle, and dedicates an entire chapter to it. This guidebook derives the rights and responsibilities of citizenship from the 800-year-old British Magna Carta (1215) and the Canadian Charter of Rights and Freedoms (1982) (to be discussed in detail shortly). Like all previous guidebooks, Discover Canada emphasizes the responsibility of the newcomer to know English or French as well as basic Canadian history. This similarity to previous guidebooks shows a consistency in the representation of Canada as a bilingual country well as the core values that are characteristic of the nation that all newcomers are expected to know.

Many chapters in Discover Canada are the same as the chapters in A Look at Canada. These include chapters on the different regions of Canada, Canadian history, how to apply for citizenship, the justice system, federal elections, study questions, and additional contact numbers and general information regarding the citizenship process. In addition, new chapters have been added to Discover Canada, while chapters on "Aboriginal People," "Sustainable Development," and "Map of Canada" that appeared in the previous guide are absent in the new guide. In their place is a more thorough, longer chapter on "Canadian History" (ten pages of the guidebook, as opposed to two pages in the previous guide), as well as chapters titled "Modern Canada," "Who We Are," "Canada's Economy," and the "Rights and Responsibilities of Citizenship."

What vision of Canada does Discover Canada present to readers? According to some scholars (Joyce, 2014; McKay and Swift, 2012), whereas A Look at Canada presented Canada as a "peaceable kingdom," Discover Canada presents Canada as a "warrior nation." Of all the guidebooks, Discover Canada places the greatest emphasis on Canadian military achievements. 
The entire chapter on Canadian history presents a series of events revolving around wars and battles, including the battles between First Nations and French settlements in the 1600s (p. 15), the Battle of the Plains of Abraham in 1759 (p. 15), Loyalists fleeing America (p. 15), the War of 1812 (p. 17), the Rebellion of 1837-38 (p. 17), and significant battles in the First and Second World Wars (p. 21-23). The guidebook goes so far as to include propaganda for the armed forces: the guide states that to join the military is a "noble way to contribute to Canada and an excellent career choice" (p. 9) and goes on to explain the different ways of serving and to provide a website link for further information. Nowhere in the rest of the guide are other career opportunities or avenues mentioned. Lastly, there is an entire page devoted to the Victoria Cross, the "highest honour available to Canadians [which is] awarded for the most conspicuous bravery...or selfsacrifice" (p. 41) along with a list of six of the ninety-six Canadians who have received it. In this sense, Canada is presented as a "masculine" warrior nation with a glorified military history (most of which happened before Confederation).

Constant mention of Canada's connection to Great Britain through both the text and images evoke within the reader not only a sense of loyalty to Canada but to Britain as well. Whereas previous guides took pride in Confederation and subsequent laws and policies that cut Canada's ties to and dependency on Britain, Discover Canada seems to recreate a legal and emotional relationship that today is mainly regarded as symbolic. For example, no other guide mentions the significance of the Magna Carta because the Magna Carta is not actually a part of Canadian history. Additionally, Sobel (2015) points out that the words United Kingdom (47 mentions) and England (31 mentions) are the most frequently used words throughout the guide, directing the reader's attention to the idea that Canada is in some way still an extension of Great Britain. Furthermore, the first photograph in Discover Canada (after the title page) is one of 
Queen Elizabeth II beside the oath. ${ }^{12}$ Another photograph connecting Canada to Britain (in the chapter "Canadian Symbols") is of the Canadian Crown, accompanied by text that explains its importance and the symbolism of Canada's ties to the British monarch (p. 39). Lastly, the following page presents lyrics not only to the Canadian national anthem, O Canada, but to Britain's God Save the Queen as well.

As a last point regarding the guide's vision of Canada and the emotion the guide tends to evoke, the last chapter of Discover Canada, entitled "Memorable Quotes," provides two poems by Prime Minister Sir Wilfred Laurier (1896) and Prime Minister John Diefenbaker (1957). Both quotations are accounts of what Canada means to these historical figures. Although this is not testable material (as the guide states), these quotations are reminiscent of the structure of the first guidebook, A Pocketful of Canada, which attempted to capture the spirit and soul of Canada through the use of stories, quotations and poetry. In this sense, Discover Canada presents Canada not only through an historical, factual lens, but through emotions such as the patriotism of those who worked hard to establish the nation as we know it today.

The rights and responsibilities of citizenship are listed throughout the guidebook; however, they are explicitly stated in the chapter titled "Rights and Responsibilities of Citizenship" (pp. 8-) as well as in the "Authorities" (pp. 64-) chapter. The first half of "Rights and Responsibilities of Citizenship" lists some of the many rights that Canadian citizens enjoy. These rights are derived from the Magna Carta and are entrenched in the Canadian Charter of Rights and Freedoms. Some of the listed rights are freedom of conscience and religion, freedom of peaceful assembly, mobility rights, multiculturalism, habeas corpus, etc. The following page lists the responsibilities of citizenship along with brief descriptions. These include obeying the law, taking responsibility for oneself and one's family, serving on a jury, voting, helping others

${ }^{12}$ Other photographs of the Queen are found on pages 8 and 28. 
in the community, and protecting and enjoying our heritage and environment. These are the same responsibilities listed in A Look at Canada; however, there is no mention of having adequate knowledge of English or French as in the previous guidebook. Having knowledge of either of the national languages is only mentioned in the guide's "Message to the Readers" (p. 3), where newcomers are encouraged to take government-sponsored language classes free of charge in preparation for this test (p. 6).

Although it is not listed as one of the responsibilities of citizenship, it is interesting to see that the Conservative government has placed a separate information box under the heading "Defending Canada" on the same page as the responsibilities of citizenship (p. 9). This information box reads as an advertisement for the armed forces. Therefore, defending and protecting Canada is perceived to be just as important as all the other responsibilities listed, cultivating not only a sense of loyalty to the Canadian military but one of duty as well.

Page 64 of the guide, in a chapter titled "Authorities," cites statutes such as Section 5 of the Citizenship Act ("The Minister shall grant citizenship to any person who: (e) has an adequate knowledge of Canada and the responsibilities and privileges of citizenship") and Section 15 of Citizenship Regulations, explaining what entails "adequate knowledge" (i.e., identifying chief characteristics of Canadian political and military history, social and cultural history, systems of government, etc.). Thus, the government's expectations about what new Canadians need to know about Canada's history and the rights and responsibilities of citizenship references laws that predate Prime Minister Harper's arrival in office. While Discover Canada may seem to provide an awful lot of knowledge for new Canadians to master, these references to detailed history in "Authorities" justify what is considered "adequate knowledge." This not only works in favour of the government, but for citizenship candidates as well. While decisions about who was granted citizenship were subjectively made by individual judges prior to the creation of the citizenship 
test, citing the Citizenship Act and Citizenship Regulations informs the candidate about what exactly they need to firmly understand in order to gain citizenship.

Discover Canada contains no explicit mention of integration and social inclusion in Canada and what facilitates it. Diversity and inclusion are mentioned throughout $A$ Look at Canada; however, in Discover Canada, they are mentioned only briefly on page 12 . This information box, under the heading "Diversity in Canada," simply explains that although, since the 1800s, the majority of Canadians have been born in Canada, millions of ethnically and religiously diverse immigrants live and work in peace to help build and defend Canada. This blurb then lists the 12 largest ethnic groups in Canada, the main languages spoken after English, and the five largest religious affiliations in Canada. Of all the guidebooks, Discover Canada is the first guidebook to introduce various different mainstream religion groups in Canada. Lastly, this section not only discusses racial and ethnic diversity, but sexual as well, explaining that gay and lesbian Canadians are part of the multicultural fabric of Canada (forgetting to mention that it has only been legalized in 2005 and decriminalized in 1969) and receive equal protection and rights under the rule of law.

While Canada is described as an ethnically diverse nation, the majority of photographs in Discover Canada are of White Canadians participating in "Canadian activities" (e.g., playing hockey, hunting, canoeing, etc.). The few photos of racial minorities are of people who have accomplished something noteworthy (e.g., Jamaican-Canadian gold medallist in track and field, Donovan Bailey), Aboriginal people, and racial minorities celebrating traditional holidays (p. 11 and 12) accompanying a discussion of diversity in Canada. One can argue that presenting photographs in this manner promotes the idea that immigrant Canadians are encouraged to maintain their traditions. On the other hand, one can argue that it does not present the best picture of integration: instead of presenting photographs of newcomers and native Canadians in separate 
group settings, it would be more inclusive to show them working together. Lastly, one of the photographs on the guidebook's title page is a photograph of a Christian cross. Though the reason for its presence is unclear and the photo seems unnecessary (because Canada is a secular country), perhaps it symbolizes that the majority of Canadians identify as Christians, as stated in the guidebook (p. 13).

Whereas an entire chapter was devoted to Aboriginal people in the previous guidebook, in this guidebook, only short subsections are devoted to them in the chapters titled "Who We Are" (p. 10) and "Canada's History" (p. 11). In both chapters, Aboriginals are described as the first settlers of North America, settled for thousands of years before the arrival of Europeans. Although an entire chapter is not dedicated to Aboriginals, some of the information presented is more accurate than information presented in previous guides. For example, unlike $A$ Look at Canada, which only distinguished between different Aboriginal groups, Discover Canada mentions that many treaties between the British and Aboriginals were not respected (until the 1980's) and Aboriginal children were placed in residential schools, where they were prohibited from speaking their language and practising their culture, which had an adverse effect on their upbringing and wellbeing. It was not until 2008 that the Canadian government formally apologized to former residential school students (as stated in the guidebook); however, a great deal of damage (whose information is lacking in the guidebook) had already been done.

While A Look at Canada explains that the government is working on rebuilding its relationship with Aboriginal people, Discover Canada states that "In today's Canada, Aboriginal peoples enjoy renewed pride and confidence, and have made significant achievements in agriculture, the environment, business, and the arts" (p. 10). In reality, a majority of Aboriginals are fighting for self-government, continue to live in poverty on reserves in Canada, and face socioeconomic hardships, facts overlooked by this guidebook (Flanagan, 2000). Although it is 
commendable that this guidebook recognizes that Europeans brought with them many diseases to North America against which Aboriginals had no immunity and from which many Aboriginals died, the guidebook goes on to say that "Aboriginals and Europeans formed strong economic, religious and military bonds in the first 200 years of coexistence which laid the foundations of Canada" (p. 14). This statement somewhat ingenuously addresses a negative aspect of Canadian history but underplays it by "quickly matching it to a more positive note," a technique used frequently in discussions about Aboriginal issues in Canadian history (Joyce, 2014, p. 11).

The guidebook mentions that the government sponsors free English and French language training for newcomers. In a section titled "For More Information" (p. 54), information is provided on federal programs and services, and a list of additional books and videos about Canada are briefly mentioned. An information box on page 11 headed "Unity in Diversity" and quotes John Buchan, Governor General of Canada from 1935-1940, who described what integration and inclusion in Canada should look like:

Immigrant groups should retain their individuality and each make its contribution to the national character. Each could learn from the other, and... while they cherish their own special loyalties and traditions, they cherish not less that new loyalty and tradition which springs them from their union (Club of Halifax, 1937, as cited in Discover Canada, 2012).

While much of the content of Discover Canada is not all that different from the content of A Look at Canada, the overall vision of Canada it presents is entirely different from that of its predecessor. Both guidebooks present skewed, embellished narratives of Canada which are on opposite sides of the spectrum: while A Look at Canada represented Canada as a historically peaceful nation where everyone is equal and living in multicultural harmony, Discover Canada 
represents Canada as a militarized country that is still an extension of Great Britain, and therefore whose deepest loyalty continues to be to the Anglosphere. Because of this, the guide asserts that Canadian values and beliefs must continue to embody those of Great Britain (transferred from British documents such as the Magna Carta and ideas such as habeas corpus) and, therefore, those obtaining citizenship must be loyal not only to Canada but to the British Commonwealth. With this outlook, the Conservative government weakens Canadian distinctiveness and overlooks the hard work of Canadians who have strived to develop and maintain a distinct Canadian identity.

Furthermore, while Canada's military achievements are a cornerstone in Canadian history, by accentuating Canada's armed forces throughout time, the guidebook conveys the idea that it is primarily war that has shaped Canada in the $19^{\text {th }}$ and $20^{\text {th }}$ centuries. Major events such as Confederation, the Great Depression, and the rise of the welfare state are only briefly mentioned and set on the backburner of Canadian history (Joyce, 2014). Unlike the previous guide, which emphasized social history, Discover Canada exudes the narrative of the "loyal citizen" because its subtext prioritizes nationalism.

What Discover Canada fails to realize is that Canada's military history does not define this country. Perhaps the emphasis on loyalty and law enforcement are linked to the increase in scholarly debates regarding national security after the events of September 11, 2001. The Conservative government wanted to present the image of a nation that is not to be considered weak or taken advantage of. To further strengthen this argument, page 9 of the guide under the heading "The Equality of Men and Women" states that in Canada, men and women are equal, and our open and generous spirit does not extend to "barbaric cultural practices that tolerate spousal abuse, 'honour killings,' female genital mutilation, forced marriage, or other genderbased violence." Interestingly, although not surprisingly, directly below this information box is a 
photo of a black male doctor providing a woman with medical assistance and another photograph of two Muslim women wearing hijabs (cultural head scarves) and learning English. Like the image of the cross, why were these images chosen? What subliminal message is the government trying to convey to newcomers to Canada? Were photos following this blurb really necessary at all? The message relayed by this small information box reinforces the masculine, fearless, Western image of Canada that the Conservative government is trying to convey in Discover Canada. 


\section{CHAPTER NINE}

\section{Findings}

As discussed in chapter one ("Theoretical Foundations") of this MRP, Schugurensky and Myers (2003) explain that "... the main purpose of citizenship education is the development of good democratic citizens" (p. 1). For the purposes of this MRP, I have defined a good democratic citizen as "one who actively participates in the decision-making process and upholds the values of the nation" (see: page 7). Accordingly, I must now assess the efficacy with which each guidebook has informed candidates for citizenship about the importance of the democratic process, particularly voting, and highlight the themes of each guidebook in order to determine the values that newcomers are expected to uphold.

With the exception of A Pocketful of Canada (as the legal parameters for citizenship were not yet established when it was written), each government-authored citizenship guidebook emphasizes the importance of voting in a democratic society. They do so not just by explaining the voting procedure, but also by providing detailed explanations of the mechanics of the Canadian political system, e.g., descriptions of the senate, the role of the governor general, the federalist system, etc. Governments have done a commendable job of providing newcomers with consistent and informative explanations in all the government-authored guidebooks regarding the Canadian political system and how to actively participate.

Similarly, although there is no actual body of law that explicitly describes authentic Canadian values, different governments over the years have consistently presented the same Canadian values through each successive guidebook. Some of these values are now part of Canadian law, entrenched in the Canadian Charter of Rights and Freedoms. These values are include bilingualism, democracy (specifically, the Canadian democratic process), community involvement, diversity, and respecting the rights of others (as outlined in legal documents such as 
the Canadian Bill of Rights, the Multicultural Act, and the Canadian Charter of Rights and Freedoms).

While these values have come to be considered core values over time, some guidebooks have included themes that express other Canadian values, for example, environmental protection in A Look at Canada, the artistic expression of Canadian culture in Guide to Canadian Citizenship and Canada: Guide for Citizenship, and participation in the Canadian military in Discover Canada. This raises the question of whether or not the emphasis on certain "values" over others represents propaganda on the part of the government circulating the guidebooks, or whether Canadian values have changed over time. According to some scholars, (Joyce, 2014; Ivison, 2009) and journalists (Friesen, 2009), giving emphasis to certain values over others is sometimes regarded as a strategy for the governing political party to rebrand the nation in order to enhance their political agenda and instil an idea or essence of Canada within newcomers that will later garner votes during an election. Chapnick (2011) argues otherwise, and explains that to suggest that new citizenship guidebooks have been created to rebrand the country to suit a political agenda is a profound exaggeration. It is inevitable that different political parties will present slightly different visions of Canada because different parties have different ideologies about how to achieve the same goal, i.e., economic and social prosperity in Canada. Furthermore, historical and contemporary events help shape and even change party ideologies over time. This paper sides with Chapnick's (2011) theory. A thorough examination of the various incarnations of the citizenship guide demonstrated that while the general tone of each new successive guidebook is different from the previous guidebook, fundamental descriptions of what makes a good democratic citizen and information about the core values of Canada have remained the same throughout all the guidebooks and are given equal prominence. 
Pashby, Ingram, and Joshee (2014) explain that because cultural diversity is a contested cultural cornerstone of citizenship, provinces have taken steps to publish citizenship education documents that are part of the provinces' education curricula aimed at shaping dominant understandings of nationhood in immigrant children. However, despite all of the time, money, and effort the federal government has devoted over the years to educating and preparing newcomers for citizenship, how effective have these guidebooks proven to be? Does passing the test (before a judge or through a written test) actually identify newcomer Canadians of "good character"? Uppal and Côté (2014) explain that those who immigrated to Canada in 2001 or later were less likely to vote, $51 \%$ of recent citizens voted compared to $66 \%$ of more established first generation citizens, and $67 \%$ for second generation Canadians. Furthermore, voter turnout rates differ across regions of birth, with new citizens from Western/Northern Europe and Anglosphere countries (United States, United Kingdom, Ireland, Australia and New Zealand) demonstrating the highest voter turnout at $77 \%$. Even though the guidebooks and citizenship test are designed for both men and women equally, Uppal and Côté (2014) explain that gender is also a factor for voter turnout among new citizens: men from all over the world have higher voter turnout rates than women; however, the greatest differences are between men and women from African countries.

The extent to which first generation Canadians become engaged in the Canadian democratic system over time is affected by a myriad of other factors that are beyond the scope of this essay (e.g., economic well-being, education, age, trust in the system, etc.). However, the government has done its due diligence by explicitly stating the rights, responsibilities and merits of citizenship within these guidebooks, stressing that they are mandatory for all newcomers aged 14 to 64 to know. Furthermore, to determine to what extent new Canadians "uphold the values" of Canada is also extremely difficult to establish: there is no "values police" in Canada 
monitoring and punishing those who do not speak English or French, or who fail to do their community service, or who do not vote. If there is no way to determine to what extent firstgeneration Canadians participate in the democratic process or uphold Canadian values, how does the government ensure that newcomers fulfil the responsibilities of citizenship? Is a good citizen one who simply pays their taxes and abides by the law? Are citizenship requirements different for adults over the age of 65 who do not have to write the test or speak English or French, and who are granted citizenship on the basis of humanitarian and compassionate grounds? Has Canada focused so much on population growth for economic prosperity that the question of whether or not new Canadians uphold Canadian values has been set aside? Perhaps Canadian citizenship guidebooks and their content are mainly symbolic rather than being true study books to help candidates demonstrate their eligibility for citizenship.

Stephen Harper's Progressive Conservative government (2006 to 2015) is the only government that has taken measures to respond to some of these questions by making citizenship harder to acquire and easier to lose. Along with longer and stricter residency requirements, the Harper government made the citizenship test more difficult for candidates to pass by raising the pass score on the test (applicants are allowed only five wrong answers now instead of eight) and by placing more emphasis on the requirement that candidates speak English or French, while at the same time making questions about Canadian history, identity and values more challenging. The reason for these changes were explained by Jason Kenney, then Minister of Citizenship, Immigration and Multiculturalism, who stated: "We had devalued Canadian citizenship with the kind of paucity of content in the former guide and test" (Mills, 2012).

According to Statistics Canada, since the production of Discover Canada, the failure rate has jumped from 4\% in 2009 to $15 \%$ in 2011. A test-taker interviewed by the Globe and Mail stated that "Even though I studied hard, I found the test, really, really tough", observing that most 
questions were not straightforward and required critical thinking (Mills, 2012). Should immigrants fail the test, they meet with a judge for an oral citizenship hearing, and should they fail that too, they must reapply to start the citizenship process all over again, a process that can cost hundreds of dollars.

The Harper government emphasized that citizenship in Canada is less of a right and more a privilege and responsibility to be taken extremely seriously. In 2015 the Conservatives also introduced and passed a bill establishing a two-tier or "second class" citizenship system. Dual citizens and those who have immigrated to Canada are subject to losing their citizenship should they be found to be a threat to Canadian national security or convicted of a terrorist offence in Canada or in another country. Only those born in Canada without any other nationality cannot be stripped of their citizenship. Again, this law targets Muslim-Canadians in the wake of international "Islamic" terrorism and incidents of "home-grown terrorism." No judge is present during the removal process and, as a result, this law is extremely unfair and likely unconstitutional.

While he was prime minister, Stephen Harper and Jason Kenney, his minister of citizenship, immigration and multiculturalism, attempted to strengthen the concept of nationhood though various neoliberal and neoconservative policies and laws, one of which is seen in Discover Canada and with its corresponding new and more difficult citizenship test. Pashby, Ingram, and Joshee (2014) explain that this revamp in citizenship education presents specific visions of the past that are associated with the dominant group in Canada whose traditional values are glorified. This is placed in the socio-political context of international religious terrorism in the hopes of strengthening domestic unity. The Conservative government passed the Barbaric Cultural Practices Act and suggested they would implement a hotline to enable Canadians to call and report barbaric cultural practices not in line with Canadian values. This 
primarily targets and Muslim-Canadians under the guise of keeping women and children safe. The Act condemns polygamy, marriage under the age of 16, honour killings, and forced marriage — acts that were already illegal under the Canadian Criminal Code for years. To present Canadian citizenship in this manner, however, asserts a "we/they" dichotomy, in which the "we" are White, English-speaking groups with European ancestry, and "they" are immigrants, women, the poor, and Indigenous people who do not fit this dominant norm. For many years, the predominant narrative and discourse has been of Canada as a cultural mosaic, a country that celebrates diversity as a hallmark of one of our unique Canadian values. Thus, the Conservative party's latest citizenship guidebook and its amendments to Canada's citizenship laws came as a shock to many Canadians. The previous understanding of citizenship, both for newcomers and native Canadians, is now being questioned following Stephen Harper's time in office.

While Harper's policies may have thwarted our understanding of what Canadian citizenship means based on how the government prepares and tests newcomers for citizenship, outraged citizens responded in the latest election by electing Canada's current Liberal prime minister, Justin Trudeau, who has argued against Stephen Harper's regressive immigration and citizenship policies and advocated that changes be made to them. In a speech following his election win in 2016, Trudeau reaffirmed that "Diversity is our strength. In so many ways, it's the air that we breathe. This is what Canada looks like" (Trudeau, 2015). 


\section{CONCLUSION}

What we have built together in Canada is something very great and very noble. A country whose values of tolerance, understanding, generosity have made us what we are: a society where our number one priority is the respect and dignity of all our citizens.

Prime Minister Jean Chretien

After tracing the history of citizenship guides in Canada, delving into academic literature offering different perspectives, and finally dissecting, comparing and contrasting the six different guidebooks, this study has evaluated the evolution of citizenship in Canada and the many progressive changes made over time. Whereas Canada was once metaphorically described as a young thoroughbred that was problematic because it was not fully trained or grown, Canada today is an international leader in education, the economy, and sets examples for countries all over the world regarding multiculturalism and peaceful coexistence.

Seeking a full understanding of the evolution of citizenship in Canada both legally and historically exceeds the scope of this study and is beyond a simple explanation of six documents. The primary purpose of my research was to understand the government's expectations of new citizens, how newcomers are educated and prepared for life as Canadian citizens, and what values they are encouraged to embrace. This study has demonstrated that none of the six guidebooks are perfect, for none offer a representation of life in Canada that is $100 \%$ accurate. After all, everyday experiences in Canada and how citizenship is viewed differs not just from one government to the next, but from person to person as well. However, this study has argued that by examining the evolution of these guidebooks and the socio-political context in which they were developed, one can understand both the patterns and transformations of citizenship culture in Canada and what aspects of Canadian citizenship (the government believes) contribute to a stable, distinctive, citizenship identity. To determine where citizenship policy will head in the future, and what the next guidebook will look like, is of course impossible, as this study has 
revealed that socio-political changes both internationally and domestically have altered parameters of citizenship policy over time.

It is my hope that during a time in this world where wars are rampant, cultural and religious groups are targeted, and loyalties are questioned, that this study provides readers with a little more clarity as to what makes Canada a unique, beautiful, strong, and united country. From early struggles and triumphs of settlers and immigrants portrayed in A Pocketful of Canada, to accepting women and visible minorities as citizens in law, this study wants readers to realize that the strength of Canada, economically, culturally, and socially, is embedded in our diversity. Scholars continue to grapple with what Canadian values are, how to define them, and how to implement and embed them within society. Examining the Canadian citizenship guidebooks chronologically over a period of 65 years has demonstrated that themes and values such as bilingualism, multiculturalism, community service, and democracy, are truly important to Canadian prosperity and wellbeing. These values extrapolated from the six guidebooks have proved, along with countless of decades of hard work by immigrants and born-Canadians from all over the world that though far from perfect, Canada is an example to the rest of the world that people from all walks of life can live together in confidence.

\section{REFERENCES}

Aboriginal peoples of Canada: A demographic profile. (2017). Www12.statcan.gc.ca. Retrieved 
6 November 2016, from

https://www12.statcan.gc.ca/English/census01/products/analytic/companion/abor/canada.

$\underline{\mathrm{cfm}}$

Abraham Lincoln: Gettysburg Address. (2017). Greatamericandocuments.com. Retrieved 12 November 2016, from http://www.greatamericandocuments.com/speeches/lincolngettysburg.html

ARCHIVED - Forging Our Legacy. (2006). Cic.gc.ca. Retrieved 24 January 2017, from http://www.cic.gc.ca/english/resources/publications/legacy/chap-5.asp

Bauder, H. (2014). Re-Imagining the Nation. Comparative Migration Studies, 2(1), 9-27. http://dx.doi.org/10.5117/cms2014.1.bau2

Bloemraad, I. (2006). Becoming a citizen (1st ed.). Berkeley: University of California Press. Canadian Bill of Rights. (2017). Government of Canada. Retrieved 15 October 2016, from http://laws-lois.justice.gc.ca/eng/acts/c-12.3/FullText.html

Canadian Charter of Rights and Freedoms, s 7, Part I of the Constitution Act, 1982, being Schedule B to the Canada Act 1982 (UK), 1982, c11.

Canadian Citizenship Branch, Department of the Secretary of State. 1947. How to become a Canadian Citizen. Ottawa, ON: King's Printer and Controller of Stationery.

Canadian Citizenship Act, 1947. (n.d.). Retrieved July 14, 2016, from http://www.pier21.ca/research/immigration-history/canadian-citizenship-act-1947

Canadian citizenship. (2017). Government of Canada. Retrieved 23 October 2016, from http://www.cic.gc.ca/EnGLIsh/citizenship/index.asp

Chapnick, A. (2007). The Gray lecture and Canadian citizenship in history. American Review of Canadian Studies, 37(4), 443-457.

Chapnick, A. (2011). A “Conservative” National Story? The Evolution of Citizenship and 
Immigration Canada's Discover Canada. American Review of Canadian Studies, 41(1), 20-36.

Citizenship and Immigration Canada. 1995. A Look at Canada. Ottawa, ON: Minister of Government Services.

Citizenship and Immigration Canada. 2009. Discover Canada. Ottawa, ON: Minister of Public Works and Government Services.

Dahl, R., Shapiro, I., \& Cheibub, J. (2003). The democracy sourcebook (1st ed.). Cambridge, Mass.: MIT Press.

Department of the Secretary of State. 1963. Guide to Canadian Citizenship. Ottawa, ON: Queen's Printer and Controller of Stationery.

“Diversity is Canada's Strength”. (2017). Prime Minister of Canada. Retrieved 2 December 2016, from http://pm.gc.ca/eng/news/2015/11/26/diversity-canadas-strength

Flanagan, Tom. 2007. Harper's Team: Behind the Scenes in the Conservative Rise to Power. Montreal and Kingston: McGill-Queen's University Press.

Friesen, Joe. 2009. “Ottawa to Remodel Canada’s Image.” Globe and Mail, November 10. www.theglobeandmail.com (February 9, 2010).

Hebert, Y., \& Wilkinson, L. (2002). Citizenship in Transformation in Canada. Toronto: University of Toronto Press.

Hyland, J. (1995). Democratic theory (1st ed.). Manchester: Manchester University Press. Inflation Calculator. (2017). Bankofcanada.ca. Retrieved 14 November 2016, from http://www.bankofcanada.ca/rates/related/inflation-calculator/

Ivison, John. 2009. “A Tory Guide to a Blue Canada.” National Post, November 13. www.nationalpost.com (February 9, 2010).

Joyce, C. (2014) From "Peaceable Kingdom" to "Warrior Nation": A comparative analysis of the 
Liberal and Conservative citizenship study guides. Capstone Seminar Series, (Re)Negotiating Artifacts of Canadian Narratives of Identity. 4(1), 1-18.

Kaplan, W. (1993). Belonging: The Meaning and Future of Canadian Citizenship (1st ed.). Montreal: McGill-Queen's University Press.

Kelley, N. \& Trebilcock, M. (2010). Making of the Mosaic, The: A History of Canadian Immigration Policy (1st ed.). Toronto: University of Toronto Press, Scholarly Publishing Division.

Knowles, V. (2007). Strangers at Our Gates: Canadian Immigration and Immigration Policy, 1540-2006 (1st ed.). Toronto: Dundurn Press.

McKay, I. \& Swift, J. (2012). Warrior nation (1st ed.).

Mills, C. (2017). How applicants are stumbling on the final step to becoming Canadians. The Globe and Mail. Retrieved 6 November 2016, from http://www.theglobeandmail.com/news/national/how-applicants-are-stumbling-on-thefinal-step-to-becoming-canadians/article4382633/

Parliament of Canada,. (1960). The Canadian Bill of Rights. Ottawa: Parliament of Canada.

Pashby, K., Ingram, L. A., \& Joshee, R. (2014). Discovering, Recovering, and Covering-up Canada: Tracing Historical Citizenship Discourses in K-12 and Adult Immigrant Citizenship Education. Canadian Journal of Education, 37(2).

Robins, John D.. ed. 1946. A Pocketful of Canada. Toronto: W. M. Collins Sons. Schugurensky, D. \& Myers, J. (2003). Citizenship Education: Theory, Research and Practise. Encounters On Education, 4, 1-10.

Schumpeter, J. (1976). Capitalism, socialism, and democracy (2nd ed.). New York: Harper. Secretary of State. 1976. Canada. Guide for Citizenship. Ottawa, ON: Information Canada. Sobel, N. (2015). A typology of the changing narratives of Canadian citizens through 
time. Canadian Ethnic Studies, 47(1), 11-39.

Uppal, S., \& LaRochelle-Côté, S. (2014). Overqualification among recent university graduates in Canada. Statistics Canada. 